Georgia State University

ScholarWorks @ Georgia State University

\title{
Coming and Going: Spatial Heterogeneity in Gross Population Flows
}

Kyle Mangum

Georgia State University, kmangum@gsu.edu

Follow this and additional works at: https://scholarworks.gsu.edu/uwrg_workingpapers

\section{Recommended Citation}

Mangum, Kyle, "Coming and Going: Spatial Heterogeneity in Gross Population Flows" (2017). UWRG

Working Papers. 99.

https://scholarworks.gsu.edu/uwrg_workingpapers/99

This Article is brought to you for free and open access by the Usery Workplace Research Group at ScholarWorks @ Georgia State University. It has been accepted for inclusion in UWRG Working Papers by an authorized administrator of ScholarWorks @ Georgia State University. For more information, please contact scholarworks@gsu.edu. 


\title{
W. J. Usery Workplace Research Group Paper Series
}

Working Paper 2017-4-5

April 2017

\section{Coming and Going: Spatial Heterogeneity in Gross Population Flows}

\author{
Kyle Mangum \\ Georgia State University
}




\title{
Coming and Going: Spatial Heterogeneity in Gross Population Flows
}

\author{
Kyle Mangum*
}

April 2017

\begin{abstract}
This paper shows that local labor markets in the U.S. differ substantially and persistently in rates of population turnover. This fact cannot be easily explained by demographics, sectoral composition, or network centrality. Repeat migration accounts for a small fraction of the heterogeneity, and natives are more likely to exit mobile locations than immobile locations. Hence, there is a strong place component to migration propensity. The paper explores local labor market attributes that might account for higher mobility rates. There is evidence that mobile locations have more disperse and volatile income processes, but offer superior rates of human capital accumulation.
\end{abstract}

JEL codes: R23, J61

Keywords: internal migration; gross migration; regional labor markets; local labor markets

${ }^{*}$ Department of Economics, Andrew Young School of Policy Studies, Georgia State University. Correspondence address is kmangum@gsu.edu. I am grateful to Spencer Banzhaf, Patrick Coate, and Ronni Pavan for helpful comments, as well as seminar participants at Georgia State and the University of Rochester. I thank Cody Reinhardt for valuable research assistance. Remaining errors are my own. 


\section{Introduction}

The typical economic intuition on population migration is households leaving undesirable regions for more desirable ones. This neatly fits into models of utility maximization and spatial equilibrium (e.g. Roback (1982)), as the mobility of agents (or the potential thereof) arbitrages away spatial differences in utility. This is a notion of net migration-the desirable location gaining population at the expense of the undesirable, until congestion effects or other prices make the marginal mover indifferent. The dominant empirical feature of population migration, however, is that gross flows dominate net flows by an order of magnitude. Hence, gross or "excess" migration is the very means by which population reallocation occurs $!^{1}$ Though the importance of gross migration was recognized as early as Ravenstein (1885) in U.K. data and discussed in the U.S. context by Sjaastad (1962), it has received less attention in the literature than one might expect given that population reallocation is a core topic of spatial economics and regional science.2

Perhaps the mere existence of excess turnover may not be of compelling research interest by itself, since there are always plenty of idiosyncrasies among households $\mathrm{H}^{3}$ Potentially more consequential for regional economic analysis is that local labor markets exhibit persistent heterogeneity in their degrees of population turnover. That is, some locations are characterized by high mobility, both in- and out, and others have persistently low mobility. Even studies incorporating gross migration flows typically abstract from spatial heterogeneity. $\left.\right|^{4}$

Determining what differentiates mobile and immobile labor markets, and whether the

\footnotetext{
${ }^{1}$ Excess turnover was termed "migration efficiency" in an earlier literature in sociology (Galle and Williams $(1972))$.

${ }^{2}$ Notable exceptions include empirical analyses in Miller $(1973)$ and Tabuchi (1985) and regional population models of gross flows in Schachter and Althaus (1989), Kaplan and Schulhofer-Wohl (2012), Davis et al. (2013), Mangum (2015), and Monras (2015).

${ }^{3}$ Many other forms of labor market transitions are characterized by gross flows in large excess of net flows. Examples include employment states (Blanchard et al. (1990)), jobs among firms (Davis and Haltiwanger (1992), Davis et al. (2006)), and workers between firms (Fallick and Fleischman (2004), Davis et al. (2006)).

4 Coen-Pirani (2010) documented the correlation of inflow and outflow rates across U.S. states, and this paper expands the analysis in several dimensions. Notably, this paper shows that the mechanism suggested in Coen-Pirani (2010), while relevant, is not quantitatively sufficient to explain the wide degree of heterogeneity between labor markets, as elaborated below.
} 
factors are causal or incidental, is important for our understanding of local labor market dynamics. Local labor markets can provide laboratories for studying the labor market at large, as differences between places impose variation on worker outcomes. Examples of technique include studies of the labor market implications of location size (Glaeser and Maré (2001), Baum-Snow and Pavan (2012), Baum-Snow and Pavan (2013), Baum-Snow et al. (2014)), density (Bleakley and Lin (2012)), or sectoral composition (Beaudry et al. (2012)). More directly, knowing how population reallocates between places-and whether and how this differs across space-will inform our understanding of adjustment to local labor market shocks, in the spirt of Blanchard and Katz (1992).

This paper makes three empirical contributions in documenting a set of facts on local labor market mobility. First, it confirms a large degree of correlation between inflows to and outflows from local labor markets and establishes that some labor markets are persistently more mobile than others over long horizons $5^{5}$ The pattern is documented in several data sources. Second, the paper shows that compositional differences in population attributes (for example, in age and education) or in distance from other markets (in physical and in sectoral space) explain relatively little of the spatial heterogeneity in turnover rates. Moreover, the incidence of "repeat mobility," or households who have moved in the past being more likely to move again $\sqrt[6]{6}$ accounts for only a fraction of the spatial heterogeneity, and natives to mobile locations are more likely to migrate away than natives in less mobile places.

Thus, there is a place component to mobility. These descriptive exercises present the literature with a puzzle, and the paper's third contribution is to begin offering an explanation. This is not the sort of question for which there are obvious natural experiments, but some hypotheses can be tested more heuristically through cuts of the data. The paper offers several tests, focusing on differences in income distributions. First, mobility is correlated with income inequality in both raw and residual (i.e. controlling for individual characteristics)

\footnotetext{
${ }^{5}$ In most cases herein, local labor markets are defined as metropolitan areas.

${ }^{6}$ For the purposes here, it only matters that repeat migration can occur, and it is not important whether the repeat mobility is "return" (back to a previous location) or "onward" (to a new one), or whether repeat mobility is caused by an initial move or simply due to selection of households types.
} 
measurements. This feature is not imposed by the migrants, but is also present when comparing the earnings distribution of natives and non-movers as well. Furthermore, migrants to and from mobile locations have more volatile income processes pre- and post-move than do migrants to and from less mobile locations. These facts suggest mobile labor markets have more uncertain distributions of income match quality, which could plausibly cause higher rates of inflow and outflows simultaneously.

Secondly, mobility is not obviously related to local mean incomes in the spatial cross section. However, mobile locations do show evidence of superior human capital accumulation. Earnings accelerate over the life cycle more quickly for workers in mobile places (not just among the migrants), an effect present even when controlling for market size. Additionally, migrants' incomes show a pattern consistent with human capital accumulation, earning at relative penalties when moving from immobile place to mobile, and retaining wage premia when migrating from mobile to immobile. Human capital accumulation is also plausibly related to simultaneous inflow and outflows, making for a more attractive destination while also allowing incumbent workers to leave without sacrificing all income premia.

This paper intends to spur more research center around spatial heterogeneity in worker mobility. Mobile locations appear to be fundamentally different labor markets, which offers an opportunity for studying worker outcomes within markets and population adjustments between them.

The paper proceeds as follows. Section 2 describes the data and lays out the basic empirical facts. Robustness across samples is considered. Section 3 accounts for the role of repeat mobility. Section 4 then describes the attributes of mobile and immobile places, from which a few hypotheses emerge. Sections 5 and 6 test for differences in income dynamics and rates of human capital accumulation. Section 7 concludes. Appendices contain exhibits with auxiliary results underlying the main analyses. 


\section{Empirical Patterns}

This paper uses data from a variety of sources, and I briefly describe them before reviewing the evidence.

\section{$2.1 \quad$ Data}

The first source of migration flow data is the Internal Revenue Service's (IRS) Statistics of Income division summary files on county-to-county flows in the U.S. (IRS (2015)). Migration is inferred by the IRS from year-over-year address changes on a tax filer's return, and the IRS makes available a summary of the gross county-to-county flows 7 The data report, for each place-to-place cell, the number of tax returns (the number of households, to a close approximation) and the number of exemptions (approximately, the number of persons), and for each origin and destination county, the total inflows and outflows. I use the household-level data for 1990-2013, aggregating county-to-county flows to consistent-definition metropolitan statistical areas (MSAs, year 2000) 8

The dataset affords several advantages. First, the data contain actual gross flows between location pairs-i.e., the migration network-for a wide swath of U.S. geography. Second, the data are reported annually, a high frequency for studies of migration, and reveal migration patterns over time. Third, the dataset is nearly a census of migration flows, an advantage over even large microdata samples. However, it is a census of taxpayers only, so those who earn little income or otherwise do not file taxes are not represented.

The major disadvantage of the data is that it is an aggregation, so there is no information on the individual households composing the flows. Therefore, I also employ three workhorse microdata sources provided by the IPUMS project (Ruggles et al. (2015)). I use the five

\footnotetext{
${ }^{7}$ The IRS suppresses cells with fewer the 10 households, although the data also include a summary of total county-level inflows and outflows which include migrants on censored county pairs. For the few of my analyses that use the full place-to-place flow matrix, the data preparation includes an imputation procedure for censored observations based on known county inflows and outflows, past and future observed flows for the county pair, and proximity. The censoring is a more severe problem for flows between rural counties than among the urban areas that are the focus here.

${ }^{8}$ For exposition, I exclude cities with a high share of workers in military occupations.
} 
percent sample of the 2000 decennial census and the 2006-2011 American Community Survey (ACS), and some ancillary analyses rely on the March Current Population Survey (CPS, Flood et al. (2015)). The census samples include retrospective questions on MSA and state of residence five years ago (one year ago in the ACS), which allow observation of one migration event.9 The Census and ACS data also provide the main sources of information on cross sectional differences in populations composition and income between locations. Finally, for some longitudinal analyses, I turn to the Panel Study of Income Dynamics (PSID (2014)). The major advantage is its longitudinal structure, reporting the dynamic path of location decisions jointly with income. The major disadvantage is its relatively small sample. The geography available in the PSID is state.

\subsection{Correlation in Population Flows}

I now turn to the primary descriptives. Figure 1, plot A, displays the initial empirical fact, the relationship between population inflows and outflows, at the metropolitan level using the IRS data. The inflow and outflow rates are calculated as a proportion of the start-ofyear population. Clearly, there is a strong correlation between inflows and outflows: cities that receive migrants send away a remarkably similar magnitude. If the empirical pattern of migration were one of spatial arbitrage-population leaving bad locations and entering good locations-this line would have negative slope. With the strong positive correlation, net migration rates average less than half of a percent, meaning gross flows are an order of magnitude larger. The most mobile labor markets have three to four times the population turnover of the least mobile markets.

In a long enough horizon, this pattern could arise if local cycling caused cities to gain population in some years and lose it in others. Plots B, C, and D shows this is not the case. Plot B shows the contemporaneous metro-by-year rates of inflow and outlaw, which

\footnotetext{
${ }^{9}$ It is possible that a person leaves a state/MSA and returns before five years; this would be coded as non-migration. Census responses for location may not be the person's tax address reported to the IRS. This distinction is apparent in cities with a relatively large share of student population ("college towns").
} 
Figure 1: Correlations In Gross Population Flows, 1990-2013
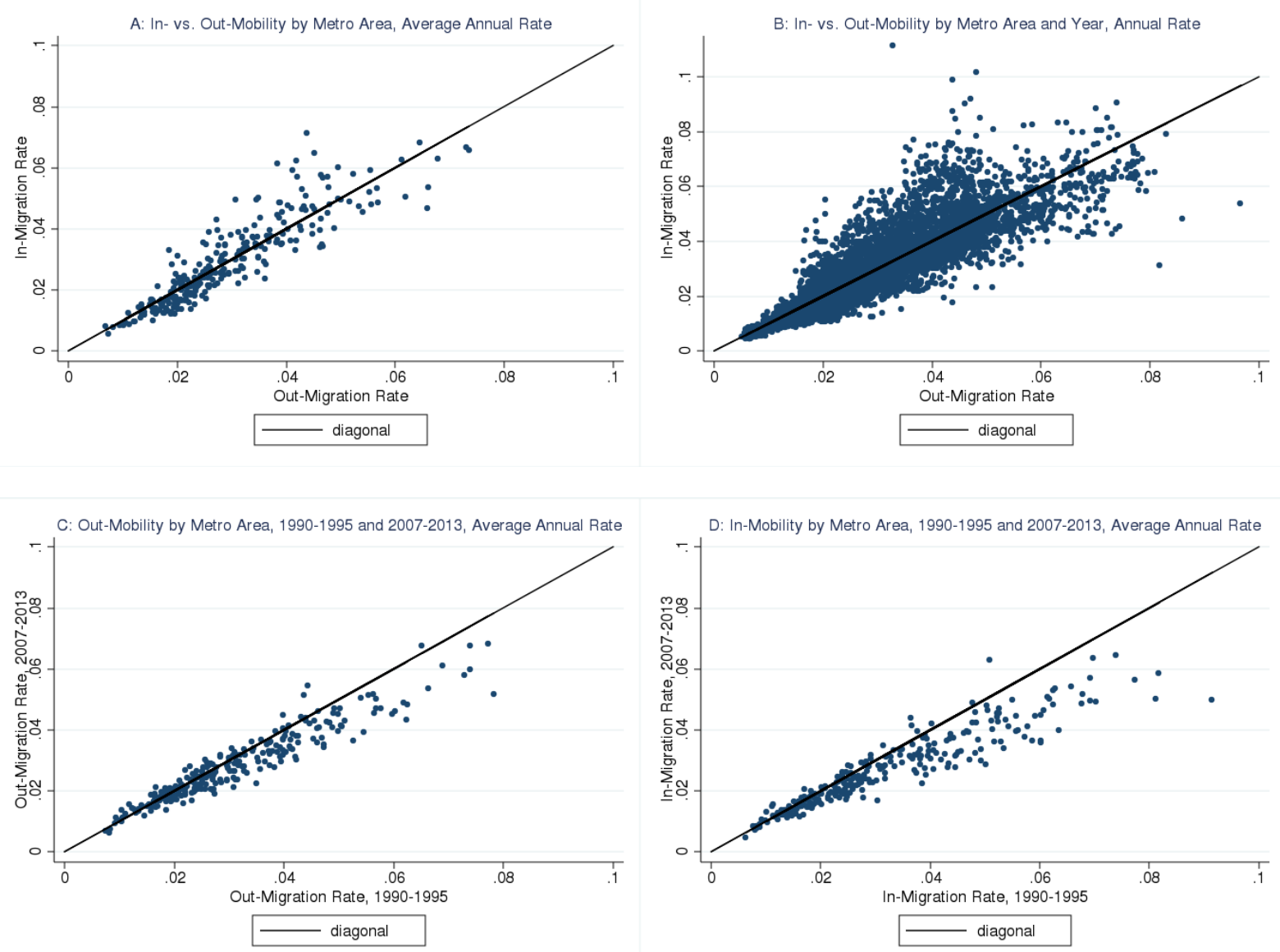

NOTES: Each dot represents a metro area, except in plot B, where a dot is a metro area-year. Source: IRS migration flow raw data.

are nearly as correlated as the averages in plot A. Plots $\mathrm{C}$ and D show the persistence in flows. Plot $\mathrm{C}$ shows the average gross outflow from the metro area for the early years of data (1990-1995) plotted agains the end of the data (2007-2013), and plot D does the same for inflows. While there is a general decline in mobility over this horizon (see Molloy et al. (2011) and Kaplan and Schulhofer-Wohl (2012)), the persistence in spatial heterogeneity is strong. Rank correlations are about 0.95 .

\subsection{Robustness}

The rest of the paper is devoted to unpacking why some locations are persistently more mobile than others. But before proceeding, some initial robustness checks are in order. 
Table 1 reports on mobility measures from across samples and compares raw mobility rates with indices that control for some potential explanations for the spatial heterogeneity in mobility.

\subsubsection{Network Distance}

One explanation is that certain locations are more centrally placed in space and might be more accessible than remote areas. Network centrality could apply to physical space as well as "similarities," broadly defined, including sectoral composition of the labor market. An easy way to test for this is through the well-known gravity model of migration.10 The regression model is

$$
m_{j k t}=\theta_{0}+\theta_{1} s_{j}+\theta_{2} s_{k}+f\left(D_{j k}\right)+\alpha_{j} X_{j t}+\beta_{k} X_{k t}+d_{t}+d_{j}+d_{k}+\varepsilon_{j k t}
$$

where $m_{j k t}$ is the $\log$ flow between origin $i$ and destination $j$ in year $t, \theta_{1}, \theta_{2}$ account for market size, $f\left(D_{i j}\right)$ is a pairwise (origin-destination) function of distance, $X_{j}, X_{k}$ are origin and destination attributes, and $d_{j}, d_{k}$ are original and estimation fixed effects. $d_{t}$ is a time dummy to account for trends in migration nationally.

The IRS migration data provide the full matrix of gross place-to-place flows and are therefore best suited for a gravity model using pairwise measures of distance. The objects of interest here are the origin and destination fixed effects, as these recover the average outand in-mobility unexplained by network distance. Table 1 reports the correlations between several specifications, with panels read as a matrix. The diagonal of a panel contains the correlations between origin and destination index for each specification. The lower triangle is the correlation between specifications in the origin mobility index; for example, between the raw outflow and a gravity adjusted origin fixed effect. The upper triangle does the same for the destination side.

\footnotetext{
${ }^{10}$ The gravity equation is a common tool for measuring migration elasticities; see Greenwood (1975). Its microfoundations from utility theory are developed by Niedercorn and Bechdolt (1969).
} 
Table 1: Correlation Within and Between Alternate Mobility Indices

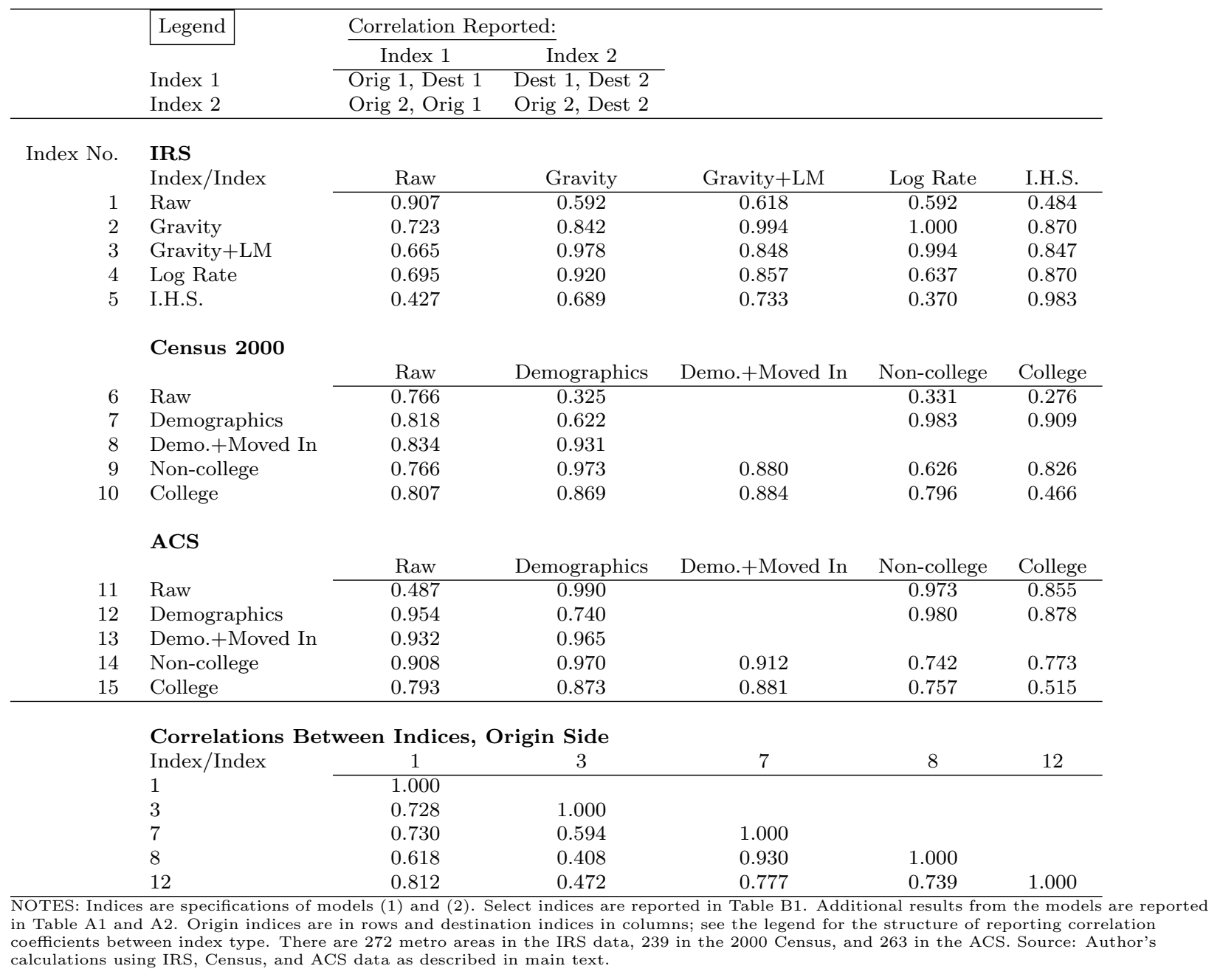


The table focuses on the relationships between indices, but the underlying regression results are in Appendix Table A1, and I also briefly discuss these. Index 2 introduces a linear-in-parameters distance function of $f\left(D_{i j}\right)$ including the physical distance between metro areas in log miles, and three measures of labor market similarity, the difference in college attainment rates, the difference in market population sizes, and a sum of differences in the employment share by industry (by NAICS category). All of these enter negatively, meaning differences between metro areas are associated with less migration flow (in either direction) between the pair. Empirically, the log miles term is most important. This is because most migration is regional, with 60 percent of between-metro migrants staying within census division and 70 percent within census region. But the distance function does not reduce the variance across the location fixed effects, and the correlation of the origin fixed effect with the raw out rate is 0.72 , meaning the gravity adjustment does little to change the rank correlations-mobile locations are still mobile controlling for distance, broadly defined, so some other forces are at work ${ }^{11}$ (Index 2 is reported for the full set of metro areas in Appendix Table B1.)

Index 3 accounts for cyclical and long term labor market trends by including measures of the local unemployment rate, wages, and residential costs. Each of these has the expected sign as "attractor" or "repellant" to population. Finally, indices 4 and 5 are specification checks, the former fixing $\theta_{i}=1$, so that outflows is measured as a rate, and the latter using the inverse hyperbolic sine instead of the log so that pairwise flows of zero can be included in the regression. But throughout the IRS panel of Table 1, correlations are positive and large. Reading down the diagonal, it is clear that distance and local labor market controls do little to break the correlation between inflows and outflows. Comparing indices with the raw rates and each other shows that various specifications of a gravity model do not change the rank pattern of spatial heterogeneity. Hence, a basic gravity explanation is unsatisfying.

\footnotetext{
${ }^{11}$ In many cases, actually, gravity fails to explain why so many coastal markets (especially west coast), which are remote by construction, are highly mobile. See Table B1.
} 


\subsubsection{Compositional Differences}

A second explanation is demographic. Mobile locations might simply have more population share in typically mobile groups-the young, the college educated, the single, etc. Such an "explanation" only pivots the question, in a sense, from understanding spatial heterogeneity in mobility to heterogeneity in attractiveness or production of certain types of groups, and moreover, why these places might be "layover" cities, attracting disproportionate share of migrants that are soon to leave. Regardless, I actually find a limited role for demographic explanations, meaning there is a large degree of residual spatial heterogeneity.

To address questions of individual characteristics, I turn to the census microdata sources. To form indices of out and in-mobility from microdata, I run regressions of

$$
I\left(\text { move }_{i j}\right)=\beta X_{i}+d_{j}+\varepsilon_{i}
$$

where $I\left(\right.$ move $\left._{i j}\right)$ is an indicator variable for whether the individual migrated from origin $j$ according to the retrospective question, $X_{i}$ is a vector of individual attributes and $d_{j}$ is the location fixed effect of interest. I control for age-by-education categories, race, immigrant status, and household composition, limiting the sample to working age adults not enrolled in school ${ }^{12}$ I do this for the origin and destination side since the census offers information on last (origin) and current (destination) location of residence. The coefficients for the attributes are reported in Appendix Table A2, but there is nothing surprising, so I do not discuss.

Index 7 of Table 1 uses the demographic controls on 2000 census data (five year migration rate) and index 12 on ACS data (one year rate). Each of these indices are still highly correlated with the raw outflow rate. The destination side is also correlated, though to a lower extent. Monras (2015) shows that population inflows are more sensitive to local

\footnotetext{
${ }^{12}$ The respondents may have been enrolled in school in the year or five years prior, at their previous location. Inspection of the data reveals that several well-known "college towns" (e.g. Bloomington, IN, Athens, GA, College Station, TX) have inordinate amounts of migration in the census data. I account for college towns by including a measure of the share of adults enrolled in college or in the education profession.
} 
labor market conditions than are outflows; for example, bad labor markets do not send more migrants than usual, but they attract many fewer in-migrants. Thus, in general, we should expect origin indices to be more persistent and more similar across specifications. Hence, I use origin indices as my preferred measures of local migration rates, especially when the full matrix of flows is not available.

Indices 8 and 13 add one more important modification-a control for whether the respondent was "at home," that is, residing in their state of birth, in the origin location. Thus, if a location appears to be mobile because it has a lot of transplant residents who are likely to move on again, this index would account for the non-natives living there. (By definition, there is no destination equivalent of this specification.) The correlation with the raw index remains, and the correlation between it and the demographics-only index is very high. Thus, spatial heterogeneity in mobility rates is apparent even after controlling for a location's history of in-migrants. This is a key result, and I will return to the repeat mobility issue in more depth in the next section.

Finally, indices 9 and 10 (14 and 15 for ACS) split the sample into non-college educated and college educated workers, who may face different labor market opportunities. Mobile locations are similarly mobile for both sets of workers, especially on the origin side. One interesting aside, however, is the relatively low correlation for in- and outflow rates among the college educated, which could be due to the ongoing concentration of educated workers in certain locations (Moretti (2013), Ganong and Shoag (2013), Broxterman and Yezer (2015), Diamond (2016)).

The bottom panel of the table reports the correlations in the origin side indices across specifications. Cities are measured to be similarly mobile across datasets with different structures, timelines, and forms of reporting. ${ }^{13}$ The patterns are robust to controls for network distance or demographic explanations. So then, what makes a mobile location?

\footnotetext{
${ }^{13}$ The lowest across-index correlations involve the gravity adjusted IRS index, which assigns slightly higher values to coastal locations.
} 


\section{Repeat Mobility}

As alluded to earlier, one possible mechanism is that a location is mobile because it was mobile before. That is, if "repeat mobility" is common, locations with a larger share of nonnative residents will exhibit more turnover as a consequence of their transient composition. ${ }^{14}$ The literature has long recognized that movers are likely to move again, whether "return" (to a previous location) or "onward" (to a never-visited location) (Herzog and Schlottmann (1982), DaVanzo (1983), Kennan and Walker (2011)).

Repeat mobility is the chief mechanism by which Coen-Pirani (2010) generates correlation in gross inflows and outflows. In that paper's model, new arrivals to a location are more likely to find themselves mismatched, and therefore more likely to move away. Long time residents, on the other hand, are a selected sample of those positively matched. When paired with persistent productivity shocks, growing locations will have more in- and out-mobility than the average location. Indeed, the mobile locations tend to be growing in population. For example, the correlation in population growth and the gravity adjusted index is 0.49 . Perhaps mobile places are simply attractive to in-migrants, many of whom turn around and leave again, and that is sufficient explanation.

The data indicate there is more to the story than repeat mobility alone. While I concur with the existing literature that one-time migrants are more likely to move again, this is insufficient explanation for the marked spatial heterogeneity between local labor markets. I investigate this empirically by estimating versions of the following equation.

$\operatorname{Pr}($ move $)=\beta X+\alpha_{1}$ orig_mobility $+\alpha_{2} I($ not_at_home $)+\alpha_{3}$ orig_mobility $\times I($ not_at_home $)+\epsilon$

where orig_mobility is an origin's mobility index and I(not_at_home) is an indicator for whether the individual had migrated in to that origin from elsewhere. If repeat mobility

\footnotetext{
${ }^{14}$ I use "native" to refer to region of birth domestically, not status as an immigrant from a foreign country.
} 
explains spatial heterogeneity, including this term will drive the mobility index coefficient toward zero. The interaction then measures whether in-migrants are more or less likely to move out of mobile places than immobile.

In the census data, "not at home" is indicated by whether the person was in a location other than his birth state. For example, a California-born resident of Los Angeles is "at home," but those born outside of California are not 15 Unfortunately, the data do not indicate when an out-of-state born person moved in (whether as a child or working age adult) or how many moves occurred prior, but this forms the best available measure relevant for the fundamental idea-that transplants are more likely to leave. The longitudinal structure of the PSID allows me to separately control for whether the origin is "home" (the place of residence in childhood) and whether the respondent moved in from elsewhere, though the spatial detail is limited to states.

Notice that by controlling generically for transplant status, specification (3) accounts for many factors that might underlie repeat mobility and focuses on the effect of it on spatial heterogeneity in mobility rates. It is agnostic as to whether subsequent moves for transplants are more likely because of a causal force-e.g. people are more likely to dislike a new place than a familiar one--or mere selection of people with idiosyncratically low moving costs. The point of emphasis is what happens to the origin mobility index coefficient.

Table 2 reports the results for several samples. In all cases, I use indices of origin mobility from out of sample. Columns 1 and 2 report results for census data, using the IRS-based gravity adjusted index and the ACS index, respectively. Columns 3 and 4 use the ACS index, but separately for the non-college and college educated sample. Column 5 is ACS data using a census index, and Column 6 is PSID using an IRS index.

Model 1 controls for individual attributes besides transplant status. In all cases, the mobility index is positively associated with an individual's migration probability. At these coefficient sizes, a standard deviation increase in the origin's mobility rate leads to an increase

\footnotetext{
${ }^{15}$ For metros crossing state lines, any state of birth in the metro area is considered at home (e.g. New Jersey-born New York MSA residents are natives).
} 
Table 2: Regressions of Mobility Controlling for Transplant Status

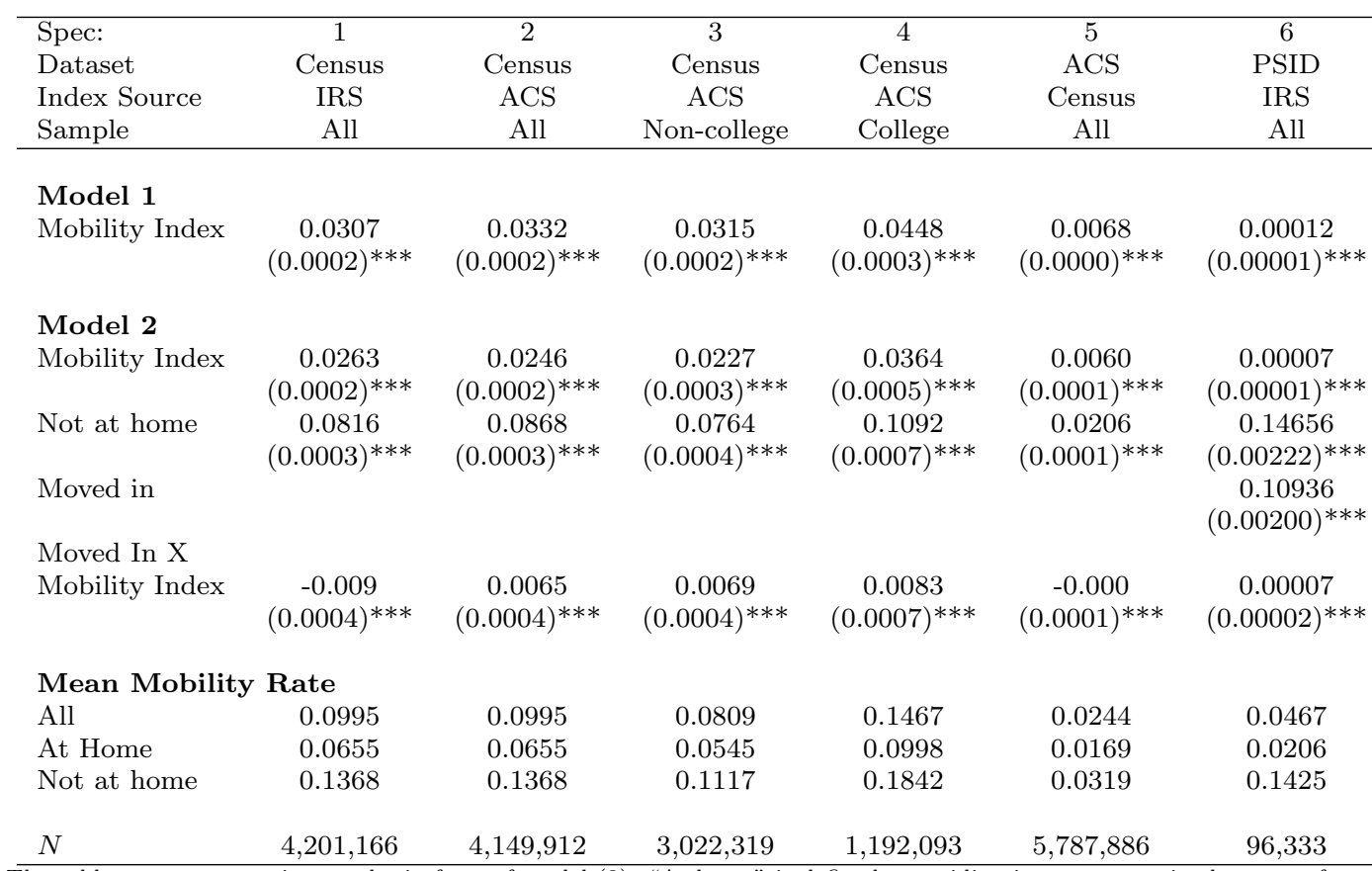

NOTES: The table reports regression results in form of model (3). "At home" is defined as residing in metro area in the state of one's birth; this can be distinguished from a recent move in the PSID only. All models include controls for age by education, household structure, race and nativity. Census and ACS data control for the metro area's share of college students. ACS includes year dummies. Source: Author's calculations using IRS, Census, ACS, and PSID data as described in main text.

of $30 \%$ in the individual's migration probability. Model 2 introduces the control for transplant status, but this only reduces the index coefficients to a 24-26 percent effect. Thus, even controlling for incumbency, mobile places are still substantially more likely to send away migrants. Moreover, a positive interaction term indicates that transplants are actually even more likely to re-migrate out of mobile places than immobile, although the sign of the interaction is not robust across samples and index choices.

A simple back-of-the-envelope exercise helps to quantify the role of repeat mobility in explaining spatial heterogeneity. From column 1 of Table 2, transplants are 8.1 percentage points more likely to move than those already residing in their place of birth. If mobility rates were the same everywhere, and locations varied only in the share of transplants, then the difference between two locations $k, j$ in mobility rates would be $0.081 \cdot\left(s_{k}-s_{j}\right)$ where $s$ is the share of natives/non-transplants. In the data, the 90-10 percentile gap in mobility rates between cities is 13 percentage points, meaning the transplant shares would have to differ by an impossible 160 percentage points. Besides, such a projection would assume a 
perfect rank correlation between observed mobility rate and transplant share, which is not the case. Using demographics and transplant share to predict migration rates by city via the regressions of (3), the 90-10 difference in predicted rate is just 6 percentage points, less than half the actual gap. In an average across cities, observed demographics and transplant status can explain only one-third of the local deviation from mean migration rate. Clearly, there remains a significant place-based component to migration rates even after controlling for the tendencies and attributes of repeat migrants.

\section{Local Labor Market Characteristics}

If there is a place component to migration probability, what are the attributes of mobile places? There could, of course, be many and varied reasons across cities. This paper is intended, in part, to stimulate work on this pattern, and cannot itself find every explanation. However, local labor market characteristics, subject of a long and useful tradition of research in regional studies, are a good place to start. In particular, I will describe the relationship between local income distributions and mobility rates. There are three reasons for focusing on income distributions. First, income distributions are the most prominent features of local labor markets besides sectoral composition, and differences in local sectoral composition are not obviously driving heterogeneity in mobility, which persisted even after controlling for sectoral isolation (in the gravity models) and composition of worker types (in the census microdata) ${ }^{16}$ Second, an important strand of literature in local labor markets concerns the relationship between city size and average earnings or dispersion in earnings ( (Glaeser and Maré (2001), Baum-Snow and Pavan (2012), Baum-Snow and Pavan (2013), BaumSnow et al. (2014)), so it seems natural to extend these questions to another feature of persistent heterogeneity in local labor markets. In essence, this is another way to use local labor markets as a "laboratory" for studying the aggregate labor market. Finally, there are

\footnotetext{
${ }^{16}$ Also, Coen-Pirani (2010) found previously that inflows and outflows from local labor markets contained observationally similar workers, further suggesting that compositional changes are not driving the turnover.
} 
plausible reasons to believe that the differences in income distributions could actually be causing the in- and out-mobility and are not merely coincidental, though the particulars of this conjecture will be elaborated in more detail after observing patterns in the data.

As an initial exploration, Table 3 examines whether mobility is correlated with features of local income distributions. The columns report the correlation of the various metro level mobility indices with the rows of local income statistics. The top panel focuses on means and the bottom panels on dispersion. Measures of earnings come from the 2000 decennial census, although results using the 1990 census and the ACS are quite similar. In each panel, there is a calculation using the raw data as well as the residuals from Mincer-style regressions that control for education, experience, work hours, demographics like race and family status, and industry and occupational classifications (at the two digit level, with about two dozen categories each). Using the residuals allows for the study of peculiar place-based components after accounting for obvious compositional differences.

I being with mean earnings. The top row shows that more mobile locations have on average slightly lower earnings. However, the row using residual incomes (i.e. the city fixed effect) shows that this might be compositional, since mobile places offer higher residual incomes in at least some measures of income mobility. The next six rows split out the calculation of raw and residual means by migrant-type subsamples: workers at home (their birth location, regardless of whether they have ever moved), non-migrants (workers who were in the same labor market five years prior), and migrants (new entrants in the last five years). The correlations among incumbent residents are very similar to the full sample, suggesting the patterns are inherent in the locations themselves and are not driven by having disparate shares of transplants.

How might higher incomes be associated with more in- and out-mobility? If a local labor market offered higher incomes because of locally-specific productivity, it would be plausible that this would attract in-migrants, though there is no obvious reason why it would also propel out-migrants. Besides, income differentials of this nature should be arbitraged away 
in steady-state equilibrium through net migration and the adjustment of other local prices. Thus, there need be no pattern between and mobility and average earnings stemming from locally-specific productivity. However, there is an alternative theory relating average earnings to mobility: if a local labor market offered more substantial human capital accumulation, this could at once attract in-migrants and allow out-migration by permitting individuals to carry some of their income premium along with them upon moving. Human capital accumulation could also fail to show up as a persistent income premium in the cross section, with different people coming and going from the local market at different points of human capital stock, which would be consistent with the weak to negative correlations in Table 3. Thus, human capital augmentation seems a viable candidate for causing higher turnover. Section 6 below will look for evidence of faster human capital accumulation among higher mobility cities.

The lower panel of Table 3 displays the correlations between local income dispersion and the mobility indices. Income dispersion is strongly correlated with mobility, and high turnover locations tend to have wider (i.e. more unequal) income distributions. This is evident in several typical measures of dispersion. The pattern holds above the median (9050 percentile), but stronger still below it (50-10 percentile), though it is not driven by points farther out to the tails (99-01, 99-50 and 50-01). This suggests the mobile locations have dispersion throughout the mass of the working population, and not excessively high or low earners.

The bottommost panel shows the pattern is largely unchanged when using residual incomes. That is, mobile places tend to have a wide dispersion of income for unobserved reasons, not because of, say, a wide diversity of occupations or worker education. This is consistent with the notion that there is a place component to turnover not due to sectoral composition.

Why might income dispersion be relevant for turnover? It is a reasonable candidate for driving both in and out-mobility to the extent it comes from "match quality." If earnings outcomes are subject to idiosyncratic match quality, workers of similar observable type would 
be passing each other in and out of the city, good matches flowing in and bad matches flowing out. This is similar intuition to Coen-Pirani (2010), but not limited to new entrants. Furthermore, uncertainty about a match could also incentivize experimental migration by offering a higher option value-a worker would want to try the high variance market, and if it does not work out, he can try again elsewhere or go home again. Thus, places with high variance in incomes for any host of reasons might exhibit more mobility in and out, even driving out incumbents.

The evidence is consistent with dispersion in match distribution. Importantly, the correlation of mobility with income dispersion remains when splitting the income data by subsamples of non-migrants and workers born in the location, indicating that the dispersion comes from a local data generating process and is not imposed by having a large share of transplants. This is especially important point for considering income dispersion, since migrants could otherwise cause local income dispersion simply by having fewer income draws to "settle in" to the location. When the mobile places exhibit higher variance even among incumbents, it suggests they have a more disperse, uncertain primitive income match distribution.

In summary, mobile places do not necessarily offer higher or lower earnings on average, though the distribution of incomes is more disperse, even when controlling for a wide array of worker characteristics. Next, I investigate whether disperse match quality means more individual earnings uncertainty. Then I test the conjecture that mobile places offer superior human capital accumulation.

\section{Income Uncertainty}

Conceptually, a wide dispersion of match quality could obtain without individual uncertainty. That is, mobile locations may consistently offer the individuals incomes that are disperse in the cross section. This could generate out mobility as suggested above. However, mobility could be more greatly affected if the dispersion was also associated with greater temporal 
Table 3: Correlation Between Local Income Distribution Characteristics and Mobility Indices

\begin{tabular}{|c|c|c|c|c|c|c|}
\hline $\begin{array}{l}\text { Income } \\
\text { Data }\end{array}$ & Stat & $\begin{array}{l}\text { Index: } \\
\text { Sample }\end{array}$ & $\begin{array}{c}1 \\
\text { IRS } \\
\text { Raw }\end{array}$ & $\begin{array}{c}2 \\
\text { IRS } \\
\text { Gravity Adj. }\end{array}$ & $\begin{array}{c}3 \\
\text { Census } \\
\text { Raw }\end{array}$ & $\begin{array}{c}4 \\
\text { Census } \\
\text { Demog. Adj. }\end{array}$ \\
\hline Raw & Mean & All & -0.273 & -0.154 & -0.133 & -0.354 \\
\hline Residual & Mean & All & 0.175 & 0.184 & -0.105 & -0.089 \\
\hline \multirow[t]{3}{*}{ Raw } & Mean & At-home & -0.398 & -0.311 & -0.262 & -0.471 \\
\hline & Mean & Non-Migrants & -0.223 & -0.135 & -0.046 & -0.308 \\
\hline & Mean & Migrants & -0.418 & -0.169 & -0.449 & -0.429 \\
\hline \multirow[t]{3}{*}{ Residual } & Mean & At-home & 0.266 & 0.243 & -0.019 & 0.003 \\
\hline & Mean & Non-Migrants & 0.215 & 0.201 & -0.055 & -0.046 \\
\hline & Mean & Migrants & 0.252 & 0.212 & 0.038 & 0.001 \\
\hline \multirow[t]{10}{*}{ Raw } & StdDev & All & 0.568 & 0.487 & 0.510 & 0.482 \\
\hline & $90-10$ & All & 0.562 & 0.509 & 0.480 & 0.460 \\
\hline & 99-01 & All & 0.375 & 0.287 & 0.427 & 0.388 \\
\hline & $90-50$ & All & 0.423 & 0.392 & 0.278 & 0.266 \\
\hline & $99-50$ & All & 0.178 & 0.158 & 0.168 & 0.266 \\
\hline & $50-10$ & All & 0.606 & 0.500 & 0.539 & 0.515 \\
\hline & $50-01$ & All & 0.372 & 0.258 & 0.429 & 0.311 \\
\hline & StdDev & At-home & 0.542 & 0.522 & 0.457 & 0.466 \\
\hline & StdDev & Non-Migrants & 0.532 & 0.485 & 0.406 & 0.448 \\
\hline & StdDev & Migrants & 0.288 & 0.210 & 0.508 & 0.237 \\
\hline \multirow{10}{*}{ Residual } & StdDev & All & 0.467 & 0.530 & 0.276 & 0.342 \\
\hline & $90-10$ & All & 0.467 & 0.523 & 0.274 & 0.366 \\
\hline & $99-01$ & All & 0.439 & 0.491 & 0.253 & 0.269 \\
\hline & $90-50$ & All & 0.400 & 0.486 & 0.243 & 0.291 \\
\hline & $99-50$ & All & 0.406 & 0.461 & 0.253 & 0.285 \\
\hline & $50-10$ & All & 0.415 & 0.422 & 0.233 & 0.348 \\
\hline & $50-01$ & All & 0.274 & 0.299 & 0.141 & 0.135 \\
\hline & StdDev & At-home & 0.369 & 0.433 & 0.240 & 0.318 \\
\hline & StdDev & Non-Migrants & 0.426 & 0.531 & 0.212 & 0.313 \\
\hline & StdDev & Migrants & 0.280 & 0.242 & 0.245 & 0.174 \\
\hline
\end{tabular}

NOTES: The table reports correlation coefficients between in the metro area cross section the income distribution statistic (rows) and the mobility index (columns). Metro area index values are reported in Table B1 There are 240 metro areas with mobility indices and income data available. Source: Author's calculations using IRS, Census, and ACS data as described in main text. 
shocks to an individual's earnings. One way to test for this second layer is to measure whether migration events in and out of mobile places are associated with larger income shocks than those in to or out of immobile places.

To look at earnings dynamics, I turn to the longitudinal PSID. As before, I want to condition on observable characteristics (which may themselves be subject to trends and shocks) and focus on an otherwise unexplained place component. For each person-year observation, I use the annual March CPS to predict that person's income given their experience, education, race, occupation, industry, and location in the year of observation $t$. Then I look at residuals from this prediction over time, $y_{i t}^{e} \equiv y_{i t}-\hat{y}_{i t}$, in a regression of the following form:

$$
y_{i t}^{e}=\sum_{s=1}^{T} I(\text { move })\left[\delta_{t-s}^{\text {origin_mobility }}+\delta_{t+s}^{\text {destination_mobility }}\right]+\nu_{i t}
$$

where $I$ (move) is an indicator for a migration event and the $\delta$ 's are parameters of interest measuring the mean residual income $s$ periods before and after the move event (at $s=0$ ). These are measured relative to a non-migrating individual, and I am mainly interested in dynamics over $\delta_{s}{ }^{17}$ To maintain consistency over time in the PSID, the periods are two-year intervals, and I use four observations on each side of the move (so, eight years before and after). For exposition, I split the locations into the more mobile and less mobile halves.

The coefficients are displayed in Figure 2 and reported with standard errors in Appendix Table A3. On the origin side of the migration event, workers out of mobile places are experiencing relative declines in income (from a statistically significant ten log point premium to zero). Workers out of immobile places exhibit much flatter profiles, not significant from zero. On the destination side, incomes for movers improve over time, but much more quickly for those arriving in mobile destinations ${ }^{18}$ Taken together, it appears that mobile locations are not only more disperse in the cross-section, but also produce more volatile individual income dynamics. Both of these are centered around a move event, so the patterns suggest

\footnotetext{
${ }^{17}$ If migrants on average have higher or lower earnings, this would be swept out by the constant.

${ }^{18}$ The dynamic pattern remains when splitting the destination into return and new (to the individual) locations.
} 
Figure 2: Earnings Dynamics Pre- and Post-Move, by Location Mobility

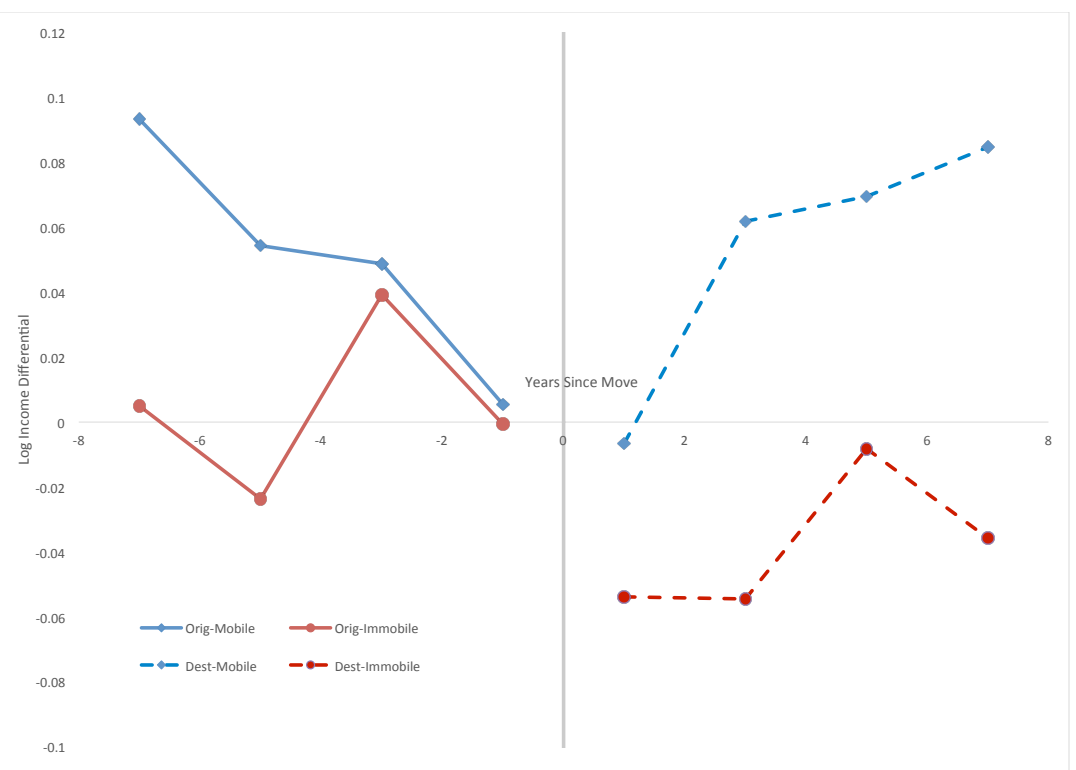

NOTES: The figure plots residual log income over time for migrants moving at a normalized time zero, indicated by the vertical line. The model is 4. Point estimates and standard errors are reported in Table A3 Source: Author's calculations using PSID, IRS, and CPS data as described in main text.

that migration from mobile places is more driven by income than migration to or from immobile places.

\section{Human Capital Accumulation}

Table 3 showed that city level mobility, in some cases, was correlated with residual income premia, though never with average incomes. I conjectured that human capital formulation could be associated with gross in- and out-mobility and fail to show up in a cross sectional correlation of mobility to incomes. I explore this conjecture further in this section. My approach to testing for superior human capital formation is similar to Glaeser and Maré (2001). First, I test whether the income-experience profile varies with mobility rates. Second, I test whether the earnings outcomes of movers (recent entrants to the local labor market) are consistent with human capital formation in their origin and destination cities. 


\subsection{The Income-Experience Profile}

The first test is to measure the income-experience profile in more versus less mobile locations to look for differences in how earnings grow as the worker gains experience. I use variants of the regression:

$$
y_{i j}=\beta X_{i}+\left(1+\gamma_{1} \text { college }\right) \times\left(\gamma_{2} \text { exper }_{i}+\gamma_{3} \text { exper }_{i}^{2}\right)+\sum_{a \in\{0: 5: 25\}} \gamma_{a} \text { exper }_{i}^{a, a+4} \cdot \text { mobility }_{j}+\varepsilon_{i j}
$$

where exper is implied experience and $X$ is a vector of worker attributes. The first terms (in parentheses) measure the typical income profile over the life cycle, interacted with college degree attainment, while controlling for the observed characteristics in $X$. The terms $\gamma_{a}$ exper $^{a, a+4} \cdot$ mobility $_{j}$ are an interaction of five-year experience categories with the location's mobility index. These measure the income profile in higher turnover locations compared to low turnover.

The results on 2000 Census data are presented in Table 4. All regressions control for available demographic characteristics, education categories, hours and weeks worked, and occupational and industry dummies. Column 1 is the basic specification, which includes dummies for the city's population size category. The experience-mobility interaction terms show that more mobile places do not offer higher incomes to young workers, but a substantial premium emerges at five years and continues through mid-career. For example, a worker with ten years experience in a city with a one standard deviation higher mobility rate earns about three percent more than the same worker in an average mobility place. For comparison, a standard deviation in mobility is worth about one and one-half years experience for a worker of this age. The premium declines into the late career, though not completely. This profile is consistent with a worker ascending the experience-earnings profile more rapidly in more mobile locations, evidence for higher human capital accumulation.

The remaining columns offer robustness checks and measurements of heterogeneity. Col- 
umn 2 adds interactions of experience dummies with log population. This reduces the experience-mobility interactions by about half, but the profile shape is qualitatively similar. Thus, some of the evidence for human capital accumulation is confounded with population size effects, but still the conjecture is not rejected. Column 3 adds MSA fixed effects to soak up average differences between cities. This requires a dropping of one experience category and a concomitant change in coefficient interpretation, but does not change the profile.

Columns 4 to 6 confirm that the observed profile is not caused by the migrants themselves, but appears to be a feature of the data generating process in mobile locations. Column 4, following Dahl (2002), adds a control function for the likelihood that a worker born in some location $j$ would reside in their observed location. There is evidence of selection (unlikely locations are associated with higher earnings), but this does not change the experiencemobility profile. Column 5 limits the sample to non-migrants, and column 6 to non-migrants in their birth location. The results are very similar to column 2 , strongly suggesting that the difference in profiles comes has a place component. Finally, columns 7 and 8 split the sample among the non-college and college educated. The profiles are similar, though slightly larger for the college educated.

In summary, mobile locations exhibit a steeper income-experience profile, with early to mid-career workers earning the largest premium relative to similar workers in less mobile locations.

\subsection{Movers Compared to Non-Movers}

Continuing to follow the logic of Glaeser and Maré (2001), I next use migrants to look for evidence of superior human capital in mobile locations. Here, I leverage the current and retrospective locations available in census data, comparing the difference in the two locations' mobility rates (though income is only observed in the current place). The logic is that if mobile locations offer more human capital accumulation, then workers have to gain experience in the mobile place to obtain a premium. Thus, recent migrants into mobile 


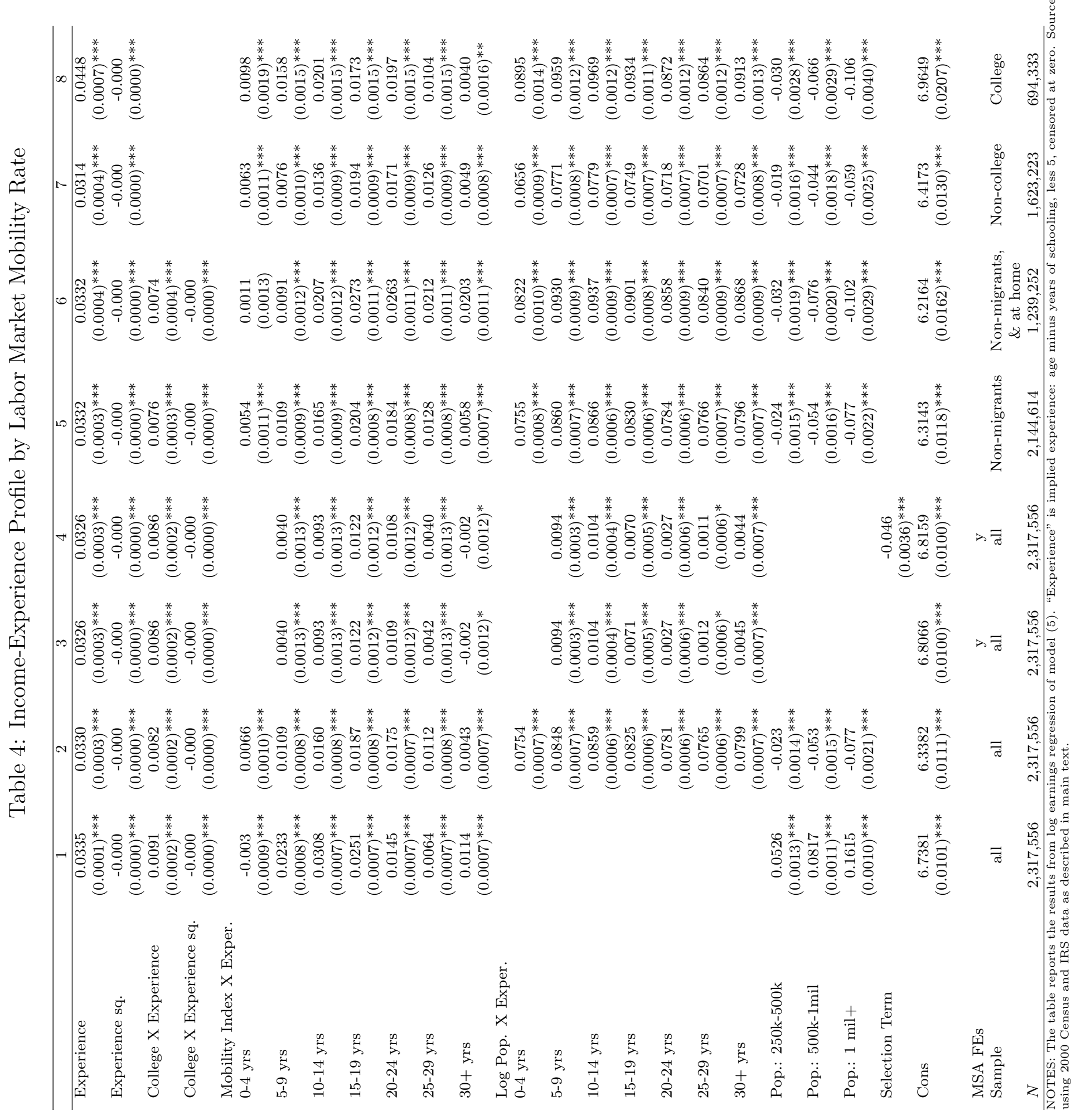


places should earn less if they came from immobile places, since they did not acquire human capital as quickly in their previous work location. On the other hand, recent migrants to less mobile locations should earn more if they came from more mobile places. Of course, an empirical test of this should account for the possible selection of workers to migrant status. I use versions of the regression:

$$
y_{i j}=\beta X_{i}+f\left(\text { exper }_{i}, \text { college }_{i}\right)+I(\text { moved }) \cdot \Delta \text { mobility }_{j k}+I(\text { moved }) \cdot I(j=\text { home })+\varepsilon_{i j}
$$

where $X$ is a vector of attributes, $f(\cdot)$ is a experience function as in (5), I(moved) indicates a migrant and $\Delta$ mobility $_{j k}$ indicates the difference in mobility rate between the past and current location. For simplicity, I will split migrants into those moving "up" (to a higher mobility place from lower) and "down" (to lower mobility). I also include controls for whether the current location is a move back to one's home (birthplace).

Table 5 reports the results. As a first check, column 1 simply includes a dummy for a migrant and another for a move home. The average migrant exhibits a very slight earnings disadvantage to an observationally equivalent worker, and moves home-possibly more likely to be occurring for non-labor market reasons-come at a income cost of about four percent. Column 2 splits the migrant dummy into moves up and down. Movers up (going from a less mobile to a more mobile place) exhibit about one percent lower incomes than observationally equivalent workers, and movers down (from more to less mobile places) earn at just under a one percent premium. These migrant patterns are consistent with a story of superior human capital accumulation in mobile cities. Workers entering mobile places earn at a penalty relative to incumbent workers, though workers exiting mobile places retain a premium in their new markets.

Column 3 interacts the move up and down dummies with the five-year experience categories. This is an important test of the conjecture because workers with less than five years 
experience typically were not working in their previous locations, their place of residence five years ago. Young workers did not accumulate local labor market experience in past locations, though older workers did. The result shows that young workers in either direction exhibit premia relative to non-migrating young workers, which could be purely a selection story. Older workers, in contrast, having accumulated experience in their past location, exhibit penalties and premia consistent with superior human capital accumulation in mobile places: movers up earn at a penalty, and movers down at a premium, especially around 1020 years experience. Columns 4 and 5 split the sample by college education to reveal some heterogeneity. Non-college educated workers seem most susceptible to the move-up penalty, while college educated workers reap most of the move-down premium. Perhaps the college educated are more able to control the circumstances under which they move.

In summary, there is evidence that mobile cities offer opportunity for superior human capital accumulation, and this could be one reason they are at once attractive to in-migrants and allow higher rates of out-mobility. This result is robust to and coincident with the well-established relationship between city size.

\section{Conclusion}

This paper has highlighted a robust but understudied feature of local labor markets, the persistent spatial heterogeneity in population turnover. This heterogeneity cannot be easily explained by demographic or compositional differences, location remoteness (in physical or sectoral space), or even by the perpetuation of turnover through repeat mobility. The paper aims to push future lines of research in regional studies, and local labor markets in particular, by documenting these patterns.

The paper then starts this agenda by suggesting that mobile locations are materially different local labor markets. In particular, mobile places have more income dispersion, income volatility, and steeper income-experience profiles. The patterns apply generally to 
Table 5: Earnings Outcomes for Movers

\begin{tabular}{|c|c|c|c|c|c|}
\hline Sample & $\begin{array}{c}1 \\
\text { All }\end{array}$ & $\begin{array}{c}2 \\
\text { All }\end{array}$ & $\begin{array}{c}3 \\
\text { All }\end{array}$ & $\begin{array}{c}4 \\
\text { Non-College }\end{array}$ & $\begin{array}{c}5 \\
\text { College }\end{array}$ \\
\hline Migrate - any & $\begin{array}{c}-0.002 \\
(0.0011)^{* *}\end{array}$ & & & & \\
\hline Migrate - up mobility & & $\begin{array}{c}-0.011 \\
(0.0015)^{* * *}\end{array}$ & & & \\
\hline x 0-4 yrs. exp. & & & $\begin{array}{c}0.0170 \\
(0.0035)^{* * *}\end{array}$ & $\begin{array}{c}0.0375 \\
(0.0051)^{* * *}\end{array}$ & $\begin{array}{c}-0.003 \\
(0.0050)\end{array}$ \\
\hline x 5-9 yrs. exp. & & & $\begin{array}{c}-0.024 \\
(0.0030)^{* * *}\end{array}$ & $\begin{array}{c}-0.009 \\
(0.0045)^{* *}\end{array}$ & $\begin{array}{c}-0.037 \\
(0.0044)^{* * *}\end{array}$ \\
\hline x 10-14 yrs. exp. & & & $\begin{array}{c}-0.006 \\
(0.0035)^{*}\end{array}$ & $\begin{array}{c}-0.019 \\
(0.0047)^{* * *}\end{array}$ & $\begin{array}{c}0.0043 \\
(0.0054)\end{array}$ \\
\hline x 15-19 yrs. exp. & & & $\begin{array}{c}-0.011 \\
(0.0039)^{* * *}\end{array}$ & $\begin{array}{c}-0.027 \\
(0.0050)^{* * *}\end{array}$ & $\begin{array}{c}0.0069 \\
(0.0064)\end{array}$ \\
\hline x 20-24 yrs. exp. & & & $\begin{array}{c}-0.002 \\
(0.0044)\end{array}$ & $\begin{array}{c}-0.029 \\
(0.0054)^{* * *}\end{array}$ & $\begin{array}{c}0.0344 \\
(0.0074)^{* * *}\end{array}$ \\
\hline x 25-29 yrs. exp. & & & $\begin{array}{c}-0.031 \\
(0.0051)^{* * *}\end{array}$ & $\begin{array}{c}-0.049 \\
(0.0063)^{* * *}\end{array}$ & $\begin{array}{c}-0.006 \\
(0.0085)\end{array}$ \\
\hline x $30+$ yrs. exp. & & & $\begin{array}{c}-0.032 \\
(0.0049)^{* * *}\end{array}$ & $\begin{array}{c}-0.053 \\
(0.0056)^{* * *}\end{array}$ & $\begin{array}{c}0.0128 \\
(0.0093)\end{array}$ \\
\hline Migrate - down mobility & & $\begin{array}{c}0.0083 \\
(0.0016)^{* * *}\end{array}$ & & & \\
\hline x 0-4 yrs. exp. & & & $\begin{array}{c}0.0377 \\
(0.0042)^{* * *}\end{array}$ & $\begin{array}{c}0.0614 \\
(0.0058)^{* * *}\end{array}$ & $\begin{array}{c}0.0125 \\
(0.0063)^{* *}\end{array}$ \\
\hline x 5-9 yrs. exp. & & & $\begin{array}{c}-0.007 \\
(0.0034)^{* *}\end{array}$ & $\begin{array}{c}0.0046 \\
(0.0047)\end{array}$ & $\begin{array}{c}-0.018 \\
(0.0051)^{* * *}\end{array}$ \\
\hline x 10-14 yrs. exp. & & & $\begin{array}{c}0.0115 \\
(0.0037)^{* * *}\end{array}$ & $\begin{array}{c}0.0039 \\
(0.0049)\end{array}$ & $\begin{array}{c}0.0191 \\
(0.0059)^{* * *}\end{array}$ \\
\hline x 15-19 yrs. exp. & & & $\begin{array}{c}0.0128 \\
(0.0041)^{* * *}\end{array}$ & $\begin{array}{c}-0.004 \\
(0.0051)\end{array}$ & $\begin{array}{c}0.0346 \\
(0.0069)^{* * *}\end{array}$ \\
\hline x $20-24$ yrs. exp. & & & $\begin{array}{c}0.0002 \\
(0.0046)\end{array}$ & $\begin{array}{c}-0.009 \\
(0.0056)^{*}\end{array}$ & $\begin{array}{c}0.0155 \\
(0.0080)^{*}\end{array}$ \\
\hline x 25-29 yrs. exp. & & & $\begin{array}{c}0.0117 \\
(0.0054)^{* *}\end{array}$ & $\begin{array}{c}-0.008 \\
(0.0067)\end{array}$ & $\begin{array}{c}0.0430 \\
(0.0092)^{* * *}\end{array}$ \\
\hline x $30+$ yrs. exp. & & & $\begin{array}{c}-0.000 \\
(0.0053)\end{array}$ & $\begin{array}{c}-0.020 \\
(0.0059)^{* * *}\end{array}$ & $\begin{array}{c}0.0452 \\
(0.0104)^{* * *}\end{array}$ \\
\hline Moved Home & $\begin{array}{c}-0.040 \\
(0.0032)^{* * *}\end{array}$ & $\begin{array}{c}-0.042 \\
(0.0032)^{* * *}\end{array}$ & & & \\
\hline x 0-4 yrs. exp. & & & $\begin{array}{c}-0.018 \\
(0.0083)^{* *}\end{array}$ & $\begin{array}{c}-0.011 \\
(0.0125)\end{array}$ & $\begin{array}{c}-0.020 \\
(0.0115)^{*}\end{array}$ \\
\hline x 5-9 yrs. exp. & & & $\begin{array}{c}-0.032 \\
(0.0063)^{* * *}\end{array}$ & $\begin{array}{c}-0.042 \\
(0.0088)^{* * *}\end{array}$ & $\begin{array}{c}-0.023 \\
(0.0093)^{* *}\end{array}$ \\
\hline x 10-14 yrs. exp. & & & $\begin{array}{c}-0.052 \\
(0.0074)^{* * *}\end{array}$ & $\begin{array}{c}-0.053 \\
(0.0098)^{* * *}\end{array}$ & $\begin{array}{c}-0.048 \\
(0.0115)^{* * *}\end{array}$ \\
\hline x 15-19 yrs. exp. & & & $\begin{array}{c}-0.036 \\
(0.0085)^{* * *}\end{array}$ & $\begin{array}{c}-0.041 \\
(0.0105)^{* * *}\end{array}$ & $\begin{array}{c}-0.032 \\
(0.0141)^{* *}\end{array}$ \\
\hline x 20-24 yrs. exp. & & & $\begin{array}{c}-0.059 \\
(0.0100)^{* * *}\end{array}$ & $\begin{array}{c}-0.054 \\
(0.0121)^{* * *}\end{array}$ & $\begin{array}{c}-0.062 \\
(0.0172)^{* * *}\end{array}$ \\
\hline x 25-29 yrs. exp. & & & $\begin{array}{c}-0.079 \\
(0.0117)^{* * *}\end{array}$ & $\begin{array}{c}-0.082 \\
(0.0141)^{* * *}\end{array}$ & $\begin{array}{c}-0.073 \\
(0.0206)^{* * *}\end{array}$ \\
\hline x $30+$ yrs. exp. & & & $\begin{array}{c}-0.046 \\
(0.0114)^{* * *}\end{array}$ & $\begin{array}{c}-0.029 \\
(0.0128)^{* *}\end{array}$ & $\begin{array}{c}-0.083 \\
(0.0230)^{* * *}\end{array}$ \\
\hline$N$ & $2,467,207$ & $2,467,207$ & $2,467,207$ & $1,600,307$ & 866,900 \\
\hline$N$ Moved Up & 146,983 & 146,983 & 146,983 & 68,119 & 78,864 \\
\hline$N$ Moved Down & 122,895 & 122,895 & 122,895 & 64,469 & 58,426 \\
\hline$N$ Moved Home & 29,756 & 29,756 & 29,756 & 15,329 & 14,427 \\
\hline
\end{tabular}


many types of workers. A possible story emerges to explain simultaneously high in- and outmobility. More disperse income distributions and more volatile income processes generate a wider degree of good matches attracting migrants and poor matches pushing them away. At the same time, by offering superior human capital accumulation, higher mobility places allow, at the margin, greater rates of inflow and outflow. These results motivate the study of local labor markets according to their mobility status much like the literature has studied the relationship between incomes and size.

More generally, the paper shows that spatial features of gross mobility should not be ignored in the study of regional economies. The patterns documented here indicate that local labor market features have implications for the rates of regional adjustment. Models of local labor market adjustment typically focus on net migration, although empirically, such adjustment occurs through a substantial degree of gross migration. With heterogenous rates of excess mobility, the growth or decline of particular local labor markets would introduce different productivity or welfare costs in the aggregate.

\section{References}

Baum-Snow, N., M. Freedman, and R. Pavan (2014). Why has urban inequality increased? http : //www.econ.brown.edu/Faculty/Nathaniel $B$ aum - Snow/capital ll $_{o}$ ct2014.pdf.

Baum-Snow, N. and R. Pavan (2012). Understanding the city size wage gap. The Review of Economic Studies 79(1), 88-127.

Baum-Snow, N. and R. Pavan (2013). Inequality and city size. Review of Economics and Statistics 95(5), 1535-1548.

Beaudry, P., D. A. Green, and B. M. Sand (2012). Does industrial composition matter for wages? an empirical evaluation based on search and bargaining theory. Econometrica 80(3), 1063-1104.

Blanchard, O. J., P. Diamond, R. E. Hall, and K. Murphy (1990). The cyclical behavior of the gross flows of us workers. Brookings Papers on Economic Activity, 85-155.

Blanchard, O. J. and L. F. Katz (1992). Regional evolutions. Brookings Papers on Economic Activity 1, 1-37. 
Bleakley, H. and J. Lin (2012). Thick-market effects and churning in the labor market: Evidence from us cities. Journal of Urban Economics 72(2), 87-103.

Broxterman, D. A. and A. M. Yezer (2015). Why does skill intensity vary across cities? the role of housing cost. Regional Science and Urban Economics 55, 14-27.

Coen-Pirani, D. (2010). Understanding gross workers flows across u.s. states. Journal of Monetary Economics 57, 769-784.

Dahl, G. B. (2002). Mobility and the return to education: Testing a roy model with multiple markets. Econometrica 70(6), 2367-2420.

DaVanzo, J. (1983). Repeat migration in the united states: Who moves back and who moves on? The Review of Economics and Statistics 65(4), 552-559.

Davis, M. A., J. D. Fisher, and M. Veracierto (2013). Gross migration, housing and urban population dynamics. Federal Reserve Bank of Chicago.

Davis, S. J., R. J. Faberman, and J. Haltiwanger (2006). The flow approach to labor markets: New data sources and micro-macro links. Journal of Economic Perspectives 20(3), 3-26.

Davis, S. J. and J. Haltiwanger (1992). Gross job creation, gross job destruction, and employment reallocation. The Quarterly Journal of Economics 107(3), 819-863.

Diamond, R. (2016). The determinants and welfare implications of us workers' diverging location choices by skill: 1980-2000. American Economic Review.

Fallick, B. and C. A. Fleischman (2004). Employer-to-employer flows in the u.s. labor market: The complete picture of gross worker flows. FEDS Working Paper No. 2004-34.

Flood, S., M. King, S. Ruggles, and J. R. Warren. (2015). Integrated public use microdata series, current population survey: Version 4.0. [machine-readable database]. minneapolis: University of minnesota. 2015.

Galle, O. R. and M. W. Williams (1972). Metropolitan migration efficiency. Demography 9(4), 655-664.

Ganong, P. and D. Shoag (2013). Why has regional income convergence in the us declined? https : $/ /$ papers.ssrn.com/sol3/papers.cfm?abstract ${ }_{i} d=2081216$.

Glaeser, E. and D. Maré (2001). Cities and skills. Journal of Labor Economics 19(2), 316-42.

Greenwood, M. J. (1975). Research on internal migration in the united states: a survey. Journal of Economic Literature, 397-433. 
Herzog, H. W. and A. M. Schlottmann (1982). Moving back vs. moving on: The concept of home in the decision to remigrate. Journal of Regional Science 22(1), 73-82.

IRS (2015). Irs migration data.

Kaplan, G. and S. Schulhofer-Wohl (2012). Understanding the long-run decline in interstate migration. NBER Working paper No. 18507.

Kennan, J. and J. R. Walker (2011). The effect of expected income on individual migration decisions. Econometrica 79, 211-251.

Mangum, K. (2015). Cities and labor market dynamics. W. J. Usery Workplace Research Group Paper Series, 2015-2-3, http : //uwrg.gsu.edu/files/2015/02/Cities - and-Labor - MarketDynamics.pdf.

Miller, E. (1973). Is out-migration affected by economic conditions? Southern Economic Journal, 396-405.

Molloy, R. S., C. L. Smith, and A. Wozniak (2011). Internal migration in the united states. Journal of Economic Perspectives 25(3), 173-196.

Monras, J. (2015). Economic shocks and internal migration. https : //papers.ssrn.com/sol3/papers.cfm?abstract ${ }_{i} d=2564973$.

Moretti, E. (2013, January). Real wage inequality. American Economic Journal: Applied Economics 5(1), 65-103.

Niedercorn, J. H. and B. H. Bechdolt (1969). An economic derivation of the 'gravity law' of spatial interaction. Journal of Regional Science 9(2), 273-282.

PSID (2014). Panel study of income dynamics, public use dataset. Technical report, Institute for Social Research, University of Michigan Survey Research Center.

Ravenstein, E. G. (1885). The laws of migration. Journal of the Statistical Society of London 48(2), $167-235$.

Roback, J. (1982). Wages, rents, and quality of life. Journal of Political Economy 90 (6), 1257-1278.

Ruggles, S., K. Genadek, R. Goeken, J. Grover, and M. Sobek. (2015). Integrated public use microdata series: Version 6.0 [machine-readable database]. minneapolis: University of minnesota.

Schachter, J. and P. G. Althaus (1989). An equilibrium model of gross migration. Journal of Regional Science 29(2), 143-159. 
Sjaastad, L. A. (1962). The costs and returns of human migration. Journal of Political Economy $70(5), 80-93$.

Tabuchi, T. (1985). Time-series modeling of gross migration and dynamic equilibrium. Journal of Regional Science 25(1), 65-83. 


\section{A Appendix: Auxiliary Results}

\begin{tabular}{|c|c|c|c|c|}
\hline Index \# & $\begin{array}{l}2 \\
\text { Gravity }\end{array}$ & $\begin{array}{l}3 \\
\text { Gravity+LM }\end{array}$ & $\begin{array}{l}4 \\
\text { Log Rate }\end{array}$ & $\begin{array}{l}5 \\
\text { I.H.S. }\end{array}$ \\
\hline Origin Size & $\begin{array}{l}0.8011 \\
(0.0152) * * *\end{array}$ & $\begin{array}{l}0.7538 \\
(0.0160) * * *\end{array}$ & & $\begin{array}{l}0.3490 \\
(0.0124) * * *\end{array}$ \\
\hline Dest. Size & $\begin{array}{l}0.5029 \\
(0.0153) * * *\end{array}$ & $\begin{array}{l}0.4999 \\
(0.0160)^{* * *}\end{array}$ & $\begin{array}{l}0.5021 \\
(0.0153)^{* * *}\end{array}$ & $\begin{array}{l}0.2179 \\
(0.0124)^{* * *}\end{array}$ \\
\hline Move & $\begin{array}{l}-2.197 \\
(0.0130)^{* * *}\end{array}$ & $\begin{array}{l}-2.189 \\
(0.0130) * * *\end{array}$ & $\begin{array}{l}-2.196 \\
(0.0130) * * *\end{array}$ & $\begin{array}{l}-1.733 \\
(0.0148) * * *\end{array}$ \\
\hline Log Mile Distance & $\begin{array}{l}-1.098 \\
(0.0013) * * *\end{array}$ & $\begin{array}{l}-1.098 \\
(0.0013) * * *\end{array}$ & $\begin{array}{l}-1.098 \\
(0.0013) * * *\end{array}$ & $\begin{array}{l}-1.256 \\
(0.0011) * * *\end{array}$ \\
\hline College Share Diff. & $\begin{array}{l}-1.850 \\
(0.0244) * * *\end{array}$ & $\begin{array}{l}-1.868 \\
(0.0244) * * *\end{array}$ & $\begin{array}{l}-1.850 \\
(0.0244) * * *\end{array}$ & $\begin{array}{l}-3.215 \\
(0.0172) * * *\end{array}$ \\
\hline Industry Dissimilarity & $\begin{array}{l}-0.007 \\
(0.0008) * * *\end{array}$ & $\begin{array}{l}-0.007 \\
(0.0008)^{* * *}\end{array}$ & $\begin{array}{l}-0.007 \\
(0.0008) * * *\end{array}$ & $\begin{array}{l}-0.034 \\
(0.0006) * * *\end{array}$ \\
\hline Size Diff. & $\begin{array}{l}-0.313 \\
(0.0014) * * *\end{array}$ & $\begin{array}{l}-0.314 \\
(0.0014) * * *\end{array}$ & $\begin{array}{l}-0.313 \\
(0.0014) * * *\end{array}$ & $\begin{array}{l}-0.502 \\
(0.0010) * * *\end{array}$ \\
\hline Orig. Unempl. Rate & & $\begin{array}{l}0.1983 \\
(0.0065) * * *\end{array}$ & & \\
\hline Dest. Unempl. Rate & & $\begin{array}{l}-0.144 \\
(0.0064) * * *\end{array}$ & & \\
\hline Orig. Wage & & $\begin{array}{l}-0.415 \\
(0.0330) * * *\end{array}$ & & \\
\hline Dest. Wage & & $\begin{array}{l}0.4291 \\
(0.0334) * * *\end{array}$ & & \\
\hline Orig. Home Price & & $\begin{array}{l}0.2591 \\
(0.0110) * * *\end{array}$ & & \\
\hline Dest. Home Price & & $\begin{array}{l}-0.118 \\
(0.0111) * * *\end{array}$ & & \\
\hline Cons & $\begin{array}{l}-2.684 \\
(0.2329) * * *\end{array}$ & $\begin{array}{l}-2.022 \\
(0.2472)^{* * *}\end{array}$ & $\begin{array}{l}-4.804 \\
(0.1665) * * *\end{array}$ & $\begin{array}{l}5.4607 \\
(0.1897)^{* * *}\end{array}$ \\
\hline$K \times J \times T$ & 581,847 & 581,847 & 581,847 & $1,714,167$ \\
\hline
\end{tabular}


Table A2: Mobility Index: Census Data Regression Results, Origin Side

\begin{tabular}{|c|c|c|c|c|}
\hline \multirow[t]{2}{*}{ Index \# } & \multicolumn{2}{|c|}{$\begin{array}{c}8 \\
\text { Census } 2000\end{array}$} & \multicolumn{2}{|c|}{$\begin{array}{ll}13 \\
\text { ACS } 2006-11\end{array}$} \\
\hline & Demographics & Demo. + Moved In & Demographics & Demo. + Moved In \\
\hline Aged 30-39 & $\begin{array}{l}-0.033 \\
(0.0006) * * *\end{array}$ & $\begin{array}{l}-0.037 \\
(0.0006) * * *\end{array}$ & $\begin{array}{l}-0.011 \\
(0.0003) * * *\end{array}$ & $\begin{array}{l}-0.012 \\
(0.0003) * * *\end{array}$ \\
\hline Aged 40-49 & $\begin{array}{l}-0.067 \\
(0.0006)^{* * *}\end{array}$ & $\begin{array}{l}-0.073 \\
(0.0006)^{* * *}\end{array}$ & $\begin{array}{l}-0.022 \\
(0.0003)^{* * *}\end{array}$ & $\begin{array}{l}-0.024 \\
(0.0003)^{* * *}\end{array}$ \\
\hline Aged 50-59 & $\begin{array}{l}-0.085 \\
(0.0006) * * *\end{array}$ & $\begin{array}{l}-0.095 \\
(0.0006) * * *\end{array}$ & $\begin{array}{l}-0.028 \\
(0.0003) * * *\end{array}$ & $\begin{array}{l}-0.030 \\
(0.0003) * * *\end{array}$ \\
\hline Aged 20-29 x College & $\begin{array}{l}0.1252 \\
(0.0029) * * *\end{array}$ & $\begin{array}{l}0.1204 \\
(0.0029) * * *\end{array}$ & $\begin{array}{l}0.0400 \\
(0.0009) * * *\end{array}$ & $\begin{array}{l}0.0384 \\
(0.0009)^{* * *}\end{array}$ \\
\hline Aged 30-39 x College & $\begin{array}{l}0.0639 \\
(0.0015)^{* * *}\end{array}$ & $\begin{array}{l}0.0598 \\
(0.0015) * * *\end{array}$ & $\begin{array}{l}0.0037 \\
(0.0007) * * *\end{array}$ & $\begin{array}{l}0.0021 \\
(0.0007) * * *\end{array}$ \\
\hline Aged 40-49 x College & $\begin{array}{l}-0.000 \\
(0.0014)\end{array}$ & $\begin{array}{l}-0.004 \\
(0.0014) * * *\end{array}$ & $\begin{array}{l}-0.006 \\
(0.0007) * * *\end{array}$ & $\begin{array}{l}-0.007 \\
(0.0007) * * *\end{array}$ \\
\hline Aged 50-59 x College & $\begin{array}{l}-0.017 \\
(0.0014)^{* * *}\end{array}$ & $\begin{array}{l}-0.020 \\
(0.0014)^{* * *}\end{array}$ & $\begin{array}{l}-0.008 \\
(0.0007)^{* * *}\end{array}$ & $\begin{array}{l}-0.009 \\
(0.0007)^{* * *}\end{array}$ \\
\hline Children, 1 & $\begin{array}{l}-0.022 \\
(0.0004) * * *\end{array}$ & $\begin{array}{l}-0.021 \\
(0.0004) * * *\end{array}$ & $\begin{array}{l}-0.008 \\
(0.0002) * * *\end{array}$ & $\begin{array}{l}-0.007 \\
(0.0002) * * *\end{array}$ \\
\hline Children, 2 & $\begin{array}{l}-0.032 \\
(0.0004)^{* * *}\end{array}$ & $\begin{array}{l}-0.031 \\
(0.0004)^{* * *}\end{array}$ & $\begin{array}{l}-0.009 \\
(0.0002)^{* * *}\end{array}$ & $\begin{array}{l}-0.009 \\
(0.0002) * * *\end{array}$ \\
\hline Children, 3+ & $\begin{array}{l}-0.031 \\
(0.0005)^{* * *}\end{array}$ & $\begin{array}{l}-0.030 \\
(0.0005) * * *\end{array}$ & $\begin{array}{l}-0.009 \\
(0.0003) * * *\end{array}$ & $\begin{array}{l}-0.009 \\
(0.0003) * * *\end{array}$ \\
\hline Race/Eth., Black & $\begin{array}{l}-0.016 \\
(0.0004)^{* * *}\end{array}$ & $\begin{array}{l}-0.015 \\
(0.0004)^{* * *}\end{array}$ & $\begin{array}{l}-0.001 \\
(0.0003)^{* * *}\end{array}$ & $\begin{array}{l}0.0001 \\
(0.0003)\end{array}$ \\
\hline Race/Eth., Hisp. & $\begin{array}{l}-0.020 \\
(0.0006)^{* * *}\end{array}$ & $\begin{array}{l}-0.013 \\
(0.0006) * * *\end{array}$ & $\begin{array}{l}-0.005 \\
(0.0003) * * *\end{array}$ & $\begin{array}{l}-0.004 \\
(0.0003) * * *\end{array}$ \\
\hline Race/Eth., Asian & $\begin{array}{l}0.0141 \\
(0.0010)^{* * *}\end{array}$ & $\begin{array}{l}0.0197 \\
(0.0010)^{* * *}\end{array}$ & $\begin{array}{l}0.0043 \\
(0.0004)^{* * *}\end{array}$ & $\begin{array}{l}0.0054 \\
(0.0004)^{* * *}\end{array}$ \\
\hline Race/Eth., Other & $\begin{array}{l}0.0448 \\
(0.0013) * * *\end{array}$ & $\begin{array}{l}0.0433 \\
(0.0013) * * *\end{array}$ & $\begin{array}{l}0.0046 \\
(0.0008) * * *\end{array}$ & $\begin{array}{l}0.0039 \\
(0.0008) * * *\end{array}$ \\
\hline Married & $\begin{array}{l}0.0000 \\
(0.0003)\end{array}$ & $\begin{array}{l}-0.001 \\
(0.0003) * * *\end{array}$ & $\begin{array}{l}-0.005 \\
(0.0002) * * *\end{array}$ & $\begin{array}{l}-0.006 \\
(0.0002) * * *\end{array}$ \\
\hline Immigrant & $\begin{array}{l}-0.001 \\
(0.0006) * * *\end{array}$ & $\begin{array}{l}-0.060 \\
(0.0007)^{* * *}\end{array}$ & $\begin{array}{l}-0.001 \\
(0.0003)^{* * *}\end{array}$ & $\begin{array}{l}-0.018 \\
(0.0003)^{* * *}\end{array}$ \\
\hline Citizen & $\begin{array}{l}-0.017 \\
(0.0007)^{* * *}\end{array}$ & $\begin{array}{l}-0.014 \\
(0.0007) * * *\end{array}$ & $\begin{array}{l}-0.004 \\
(0.0003) * * *\end{array}$ & $\begin{array}{l}-0.003 \\
(0.0003) * * *\end{array}$ \\
\hline College Town & $\begin{array}{l}0.2205 \\
(0.0081)^{* * *}\end{array}$ & $\begin{array}{l}0.1830 \\
(0.0080)^{* * *}\end{array}$ & $\begin{array}{l}0.0712 \\
(0.0040)^{* * *}\end{array}$ & $\begin{array}{l}0.0643 \\
(0.0040)^{* * *}\end{array}$ \\
\hline Not at Home & & $\begin{array}{l}0.0888 \\
(0.0004) * * *\end{array}$ & & $\begin{array}{l}0.0256 \\
(0.0002) * * *\end{array}$ \\
\hline Cons & $\begin{array}{l}0.2375 \\
(0.0083)^{* * *}\end{array}$ & $\begin{array}{l}0.2142 \\
(0.0082) * * *\end{array}$ & $\begin{array}{l}0.0904 \\
(0.0058) * * *\end{array}$ & $\begin{array}{l}0.0835 \\
(0.0058) * * *\end{array}$ \\
\hline$N$ & $4,104,864$ & $4,104,864$ & $5,827,478$ & $5,827,478$ \\
\hline
\end{tabular}

NOTES: The table reports additional coefficients from the census data mobility index model [2]. Source: Author's calculations using Census data as described in main text. 
Table A3: Incomes Dynamics for Movers in PSID, by Origin and Destination Mobility

\begin{tabular}{clllll}
\hline Years to Move & \multicolumn{2}{c}{ Origin } & \multicolumn{2}{c}{ Destination } \\
& Mobile & Immobile & Mobile & Immobile \\
\hline-8 & 0.0966 & -0.001 & & \\
& $(0.0350)^{* * *}$ & $(0.0384)$ & & \\
-6 & 0.0591 & -0.029 & & \\
& $(0.0299)^{* *}$ & $(0.0414)$ & & \\
-4 & 0.0498 & 0.0368 & & \\
& $(0.0256)^{*}$ & $(0.0339)$ & & -0.053 \\
-2 & 0.0072 & -0.003 & & $(0.0268)^{* *}$ \\
& $(0.0202)$ & $(0.0253)$ & & -0.006 & $(0.0221)$ \\
2 & & & 0.0618 & $-0.0280)^{*}$ \\
& & & $(0.0248)^{* *}$ & $(0.008$ \\
& & & & 0.0695 & -0.008 \\
& & & & $(0.0255)^{* * *}$ & $(0.0330)$ \\
& & & & 0.0847 & -0.035 \\
& & & & $(0.0277)^{* * *}$ & $(0.0319)$ \\
\end{tabular}

NOTES: The table reports coefficients and standard errors from the move event model [6]; coefficients are plotted in Figure 2 $N=63,564$. Source: Author's calculations using Census and IRS data as described in main text.

\section{B Appendix: Full List of MSAs by Mobility Index}

Table B1: Reporting of Mobility Indices (Origin Side Only)

\begin{tabular}{|c|c|c|c|c|c|c|}
\hline \multirow{2}{*}{$\begin{array}{r}\text { Rank } \\
(\text { Gravity Index) }\end{array}$} & Metro Area & \multirow{2}{*}{$\begin{array}{c}\text { Out Migration } \\
\text { Ann. Rate } \\
\text { IRS }\end{array}$} & \multicolumn{4}{|c|}{ Indices } \\
\hline & $\begin{array}{l}\text { Index: } \\
\text { Data: }\end{array}$ & & $\begin{array}{l}\text { Gravity } \\
\text { IRS }\end{array}$ & $\begin{array}{c}\text { Demo. } \\
\text { Census } 2000\end{array}$ & $\begin{array}{l}\text { Demo.+Moved-in } \\
\text { Census } 2000\end{array}$ & $\begin{array}{c}\text { Demo. } \\
\text { ACS }\end{array}$ \\
\hline & Average & 2.87 & & & & \\
\hline 1 & San Diego, CA & 5.02 & 2.71 & 1.10 & 0.78 & 0.36 \\
\hline 2 & Lawton, OK & 6.61 & 2.42 & & & \\
\hline 3 & Los Angeles-Long Beach, CA & 3.48 & 2.37 & 0.16 & -0.01 & -0.30 \\
\hline 4 & Phoenix, AZ & 3.50 & 2.31 & -0.28 & -1.32 & -0.27 \\
\hline 5 & Seattle-Everett, WA & 3.14 & 2.27 & -0.47 & -0.98 & -0.79 \\
\hline 6 & Las Vegas, NV & 4.39 & 2.24 & 0.44 & -0.82 & 0.34 \\
\hline 7 & Riverside-San Bernardino, CA & 4.96 & 1.98 & 1.20 & 1.13 & 0.28 \\
\hline 8 & Colorado Springs, CO & 6.47 & 1.97 & & & 1.26 \\
\hline 9 & Salinas-Sea Side-Monterey, CA & 6.21 & 1.87 & & & \\
\hline 10 & San Angelo, TX & 4.89 & 1.86 & & & \\
\hline 11 & Vallejo-Fairfield-Napa, CA & 3.96 & 1.80 & 0.14 & 0.02 & -0.27 \\
\hline 12 & Grand Forks, ND & 3.63 & 1.79 & & & \\
\hline 13 & Bremerton, WA & 5.55 & 1.77 & 2.26 & 1.71 & 0.74 \\
\hline 14 & Miami-Hialeah, FL & 3.15 & 1.75 & -1.19 & -1.93 & -0.79 \\
\hline 15 & Great Falls, MT & 2.87 & 1.70 & & & \\
\hline 16 & Yuma, AZ & 4.31 & 1.70 & 1.68 & 1.17 & 0.21 \\
\hline 17 & Fayetteville, NC & 7.32 & 1.64 & 4.15 & 4.03 & 2.50 \\
\hline 18 & Cheyenne, WY & 3.85 & 1.59 & & & \\
\hline 19 & Wichita Falls, TX & 4.62 & 1.57 & 1.90 & 1.90 & 1.37 \\
\hline 20 & Tucson, AZ & 4.12 & 1.54 & 0.53 & -0.26 & -0.01 \\
\hline 21 & Tampa-St. Petersburg-Clearwater, FL & 3.91 & 1.51 & 0.09 & -0.90 & 0.00 \\
\hline 22 & San Jose, CA & 5.58 & 1.49 & 1.71 & 1.73 & 0.33 \\
\hline 23 & Washington, DC & 3.46 & 1.38 & -0.15 & -0.52 & -0.60 \\
\hline 24 & Missoula, MT & 3.23 & 1.37 & & & \\
\hline 25 & Panama City, FL & 4.53 & 1.36 & 2.37 & 1.82 & 1.82 \\
\hline 26 & Clarksville-Hopkinsville, TN & 5.34 & 1.35 & 2.96 & 2.49 & 1.73 \\
\hline 27 & Iowa City, IA & 5.42 & 1.34 & 2.09 & 2.58 & 0.93 \\
\hline 28 & Rapid City, SD & 2.51 & 1.33 & & & \\
\hline 29 & Bradenton, FL & 4.21 & 1.31 & & & 1.00 \\
\hline
\end{tabular}




\begin{tabular}{|c|c|c|c|c|c|c|}
\hline \multirow{2}{*}{$\begin{array}{r}\text { Rank } \\
\text { (Gravity Index) }\end{array}$} & \multirow{2}{*}{$\begin{array}{l}\text { Metro Area } \\
\text { Index: } \\
\text { Data: }\end{array}$} & \multirow{2}{*}{$\begin{array}{c}\text { Out Migration } \\
\text { Ann. Rate } \\
\text { IRS }\end{array}$} & \multicolumn{4}{|c|}{ Indices } \\
\hline & & & $\begin{array}{l}\text { Gravity } \\
\text { IRS }\end{array}$ & $\begin{array}{c}\text { Demo. } \\
\text { Census } 2000\end{array}$ & $\begin{array}{l}\text { Demo. }+ \text { Moved-in } \\
\text { Census } 2000\end{array}$ & $\begin{array}{l}\text { Demo. } \\
\text { ACS }\end{array}$ \\
\hline 30 & Denver-Boulder-Longmont, $\mathrm{CO}$ & 2.81 & 1.30 & -2.32 & -3.27 & -2.42 \\
\hline 31 & Naples, FL & 4.20 & 1.30 & 0.76 & -0.44 & 0.71 \\
\hline 32 & Lawrence, KS & 7.36 & 1.29 & & & \\
\hline 33 & Santa Barbara-Santa Maria-Lompoc, CA & 5.69 & 1.24 & 2.08 & 2.15 & 1.36 \\
\hline 34 & Gainesville, FL & 6.79 & 1.24 & 2.59 & 2.55 & 3.45 \\
\hline 35 & Dallas-Fort Worth, TX & 2.89 & 1.23 & -0.58 & -0.88 & -0.80 \\
\hline 36 & Melbourne-Titusville-Cocoa-Palm Bay, FL & 4.29 & 1.22 & 0.93 & -0.11 & 0.76 \\
\hline 37 & Flagstaff, AZ & 6.14 & 1.21 & 1.83 & 1.47 & 1.65 \\
\hline 38 & Orlando, FL & 4.66 & 1.16 & 0.82 & -0.04 & 1.00 \\
\hline 39 & Lakeland-Winterhaven, FL & 4.77 & 1.08 & 0.40 & -0.19 & 0.93 \\
\hline 40 & Casper, WY & 2.08 & 1.07 & & & \\
\hline 41 & Bakersfield, CA & 3.97 & 1.07 & 1.36 & 1.41 & 0.04 \\
\hline 42 & Ventura-Oxnard-Simi Valley, CA & 5.16 & 1.06 & 1.66 & 1.62 & 0.69 \\
\hline 43 & Las Cruces, NM & 3.64 & 1.05 & 1.23 & 1.16 & 0.13 \\
\hline 44 & Reno, NV & 4.05 & 1.02 & 1.25 & 0.22 & 0.07 \\
\hline 45 & Pensacola, FL & 4.81 & 1.01 & 1.17 & 0.46 & 1.35 \\
\hline 46 & Abilene, TX & 4.49 & 0.99 & 1.69 & 1.94 & 2.13 \\
\hline 47 & Provo-Orem, UT & 5.55 & 0.97 & 1.34 & 1.30 & 0.91 \\
\hline 48 & Santa Fe, NM & 4.38 & 0.97 & 1.59 & 1.19 & 1.17 \\
\hline 49 & Austin, TX & 4.53 & 0.95 & 0.49 & 0.40 & -0.29 \\
\hline 50 & Myrtle Beach, SC & 4.12 & 0.93 & -0.05 & -0.54 & -0.10 \\
\hline 51 & Olympia, WA & 4.69 & 0.88 & 1.03 & 0.63 & 0.61 \\
\hline 52 & Bryan-College Station, TX & 6.61 & 0.88 & 2.76 & 3.25 & 3.27 \\
\hline 53 & McAllen-Edinburg-Pharr-Mission, TX & 2.89 & 0.87 & -0.08 & -0.02 & -0.52 \\
\hline 54 & State College, PA & 4.19 & 0.84 & -0.06 & 0.56 & 0.48 \\
\hline 55 & San Antonio, TX & 3.21 & 0.83 & 0.37 & 0.41 & -0.18 \\
\hline 56 & Spokane, WA & 3.12 & 0.78 & 0.06 & -0.33 & -0.51 \\
\hline 57 & Houston-Brazoria, TX & 2.58 & 0.78 & -0.68 & -0.90 & -0.79 \\
\hline 58 & Portland-Vancouver, OR & 2.54 & 0.77 & -0.52 & -1.13 & -0.84 \\
\hline 59 & Sumter, SC & 3.62 & 0.76 & 0.91 & 0.96 & 1.63 \\
\hline 60 & Sacramento, CA & 3.42 & 0.76 & 0.05 & -0.02 & -0.03 \\
\hline 61 & Brownsville-Harlingen-San Benito, TX & 3.51 & 0.75 & 0.75 & 0.92 & 0.14 \\
\hline 62 & Lubbock, TX & 4.67 & 0.74 & 1.50 & 1.93 & 1.29 \\
\hline 63 & Columbia, MO & 3.94 & 0.74 & 0.32 & 0.40 & 0.09 \\
\hline 64 & Ocala, FL & 3.85 & 0.70 & 0.64 & -0.13 & 0.75 \\
\hline 65 & Odessa, TX & 3.21 & 0.69 & 1.18 & 1.36 & -0.07 \\
\hline 66 & Albuquerque, NM & 3.29 & 0.69 & 0.72 & 0.27 & -0.26 \\
\hline 67 & New York-Northeastern NJ, NY & 2.09 & 0.66 & -1.16 & -0.93 & -1.04 \\
\hline 68 & Boston, MA & 3.18 & 0.66 & -1.27 & -1.10 & -0.77 \\
\hline 69 & Eugene-Springfield, OR & 3.71 & 0.66 & 0.21 & -0.36 & 0.16 \\
\hline 70 & Merced, CA & 4.96 & 0.65 & 1.38 & 1.51 & 0.68 \\
\hline 71 & Bloomington, IN & 4.64 & 0.63 & 1.64 & 2.08 & 2.24 \\
\hline 72 & Champaign-Urbana-Rantoul, IL & 4.67 & 0.61 & 0.93 & 1.30 & 1.19 \\
\hline 73 & Jacksonville, FL & 3.54 & 0.61 & & & -0.12 \\
\hline 74 & San Luis Obispo-Atascad-P Robles, CA & 5.25 & 0.59 & 2.13 & 2.43 & 1.68 \\
\hline 75 & Victoria, TX & 2.82 & 0.58 & & & \\
\hline 76 & Bellingham, WA & 3.85 & 0.55 & 0.45 & 0.25 & -0.37 \\
\hline 77 & Atlanta, GA & 2.59 & 0.55 & -0.49 & -1.05 & -0.61 \\
\hline 78 & Chicago-Gary-Lake, IL & 2.07 & 0.55 & -1.00 & -0.96 & -1.12 \\
\hline 79 & Santa Cruz, CA & 5.67 & 0.54 & 1.80 & 1.92 & 1.67 \\
\hline 80 & Fargo-Morehead, ND & 2.57 & 0.54 & 0.03 & -0.09 & -1.17 \\
\hline 81 & Amarillo, TX & 2.60 & 0.52 & 0.64 & 0.66 & 0.21 \\
\hline 82 & Billings, MT & 1.94 & 0.51 & -0.41 & -0.71 & -1.62 \\
\hline 83 & Pascagoula-Moss Point, MS & 3.84 & 0.51 & 0.86 & 0.65 & 1.15 \\
\hline 84 & Redding, CA & 3.28 & 0.50 & 0.40 & 0.53 & -0.23 \\
\hline 85 & Norfolk-VA Beach-Portsmouth, VA & 3.69 & 0.49 & 1.39 & 1.01 & 0.25 \\
\hline 86 & Bangor, ME & 2.00 & 0.47 & & & \\
\hline 87 & Corpus Christi, TX & 4.09 & 0.47 & & & \\
\hline 88 & New London-Norwich, CT & 4.49 & 0.46 & & & \\
\hline 89 & Tallahassee, FL & 4.77 & 0.46 & 1.11 & 1.01 & 1.47 \\
\hline 90 & Lafayette-W. Lafayette, IN & 4.17 & 0.44 & 1.00 & 1.35 & 0.86 \\
\hline 91 & Burlington, VT & 2.17 & 0.40 & & & \\
\hline 92 & Fresno, CA & 3.21 & 0.39 & 0.36 & 0.45 & -0.57 \\
\hline 93 & Laredo, TX & 2.33 & 0.38 & 0.04 & 0.20 & -0.58 \\
\hline 94 & Salt Lake City-Ogden, UT & 2.59 & 0.37 & -0.20 & -0.36 & -0.64 \\
\hline 95 & Bismarck, ND & 1.68 & 0.37 & & & \\
\hline 96 & Savannah, GA & 3.48 & 0.36 & 1.46 & 1.49 & 1.14 \\
\hline 97 & Charleston-N.Charleston, SC & 3.94 & 0.35 & 0.66 & 0.46 & 0.36 \\
\hline 98 & Grand Junction, CO & 2.77 & 0.35 & & & \\
\hline
\end{tabular}




\begin{tabular}{|c|c|c|c|c|c|c|}
\hline \multirow{2}{*}{$\begin{array}{r}\text { Rank } \\
\text { (Gravity Index) }\end{array}$} & \multirow{2}{*}{$\begin{array}{l}\text { Metro Area } \\
\text { Index: } \\
\text { Data: }\end{array}$} & \multirow{2}{*}{$\begin{array}{c}\text { Out Migration } \\
\text { Ann. Rate } \\
\text { IRS }\end{array}$} & \multicolumn{4}{|c|}{ Indices } \\
\hline & & & $\begin{array}{l}\text { Gravity } \\
\text { IRS }\end{array}$ & $\begin{array}{c}\text { Demo. } \\
\text { Census } 2000\end{array}$ & $\begin{array}{c}\text { Demo.+Moved-in } \\
\text { Census } 2000\end{array}$ & $\begin{array}{c}\text { Demo. } \\
\text { ACS }\end{array}$ \\
\hline 99 & Chico, CA & 4.48 & 0.31 & 1.06 & 1.26 & 1.03 \\
\hline 100 & Stockton, CA & 4.79 & 0.29 & 0.92 & 1.06 & 0.75 \\
\hline 101 & Sioux City, IA & 1.85 & 0.29 & -0.09 & 0.09 & -0.49 \\
\hline 102 & Medford, OR & 2.99 & 0.28 & -0.20 & -1.15 & 0.27 \\
\hline 103 & Goldsboro, NC & 3.24 & 0.28 & 0.41 & 0.54 & -0.70 \\
\hline 104 & Richland-Kennewick-Pasco, WA & 2.88 & 0.25 & 0.88 & 0.36 & -0.52 \\
\hline 105 & Lincoln, NE & 3.13 & 0.25 & -0.17 & 0.02 & -1.03 \\
\hline 106 & Bridgeport, CT & 4.63 & 0.23 & 0.15 & -0.23 & -0.28 \\
\hline 107 & Columbus, GA & 4.29 & 0.23 & 0.99 & 0.76 & 0.96 \\
\hline 108 & Bloomington-Normal, IL & 4.04 & 0.21 & 0.22 & 0.59 & 0.32 \\
\hline 109 & Visalia-Tulare-Porterville, CA & 3.55 & 0.21 & 0.68 & 0.79 & -0.31 \\
\hline 110 & Pine Bluff, AR & 2.54 & 0.18 & & & \\
\hline 111 & Barnstable-Yarmouth, MA & 3.88 & 0.17 & -0.33 & -0.26 & 0.07 \\
\hline 112 & Sioux Falls, SD & 1.91 & 0.13 & & & \\
\hline 113 & Manchester, NH & 4.37 & 0.11 & -0.98 & -1.25 & 0.37 \\
\hline 114 & Modesto, CA & 4.34 & 0.11 & 0.68 & 0.82 & 0.80 \\
\hline 115 & Dubuque, IA & 1.80 & 0.11 & & & \\
\hline 116 & Charlottesville, VA & 3.21 & 0.11 & 1.07 & 1.02 & 1.41 \\
\hline 117 & Yakima, WA & 2.96 & 0.11 & 0.50 & 0.36 & -0.29 \\
\hline 118 & Santa Rosa-Petaluma, CA & 3.87 & 0.09 & 0.49 & 0.56 & 0.47 \\
\hline 119 & Eau Claire, WI & 1.98 & 0.08 & -1.07 & -0.83 & -0.76 \\
\hline 120 & Portland, ME & 2.83 & 0.04 & -1.51 & -1.65 & -0.98 \\
\hline 121 & Athens, GA & 4.27 & 0.01 & 1.68 & 1.90 & 1.83 \\
\hline 122 & Durham, NC & 3.47 & 0.01 & -0.06 & -0.27 & -0.40 \\
\hline 123 & Madison, WI & 3.30 & 0.00 & -0.43 & -0.23 & -0.45 \\
\hline 124 & Waco, TX & 3.49 & 0.00 & 0.85 & 1.17 & 0.45 \\
\hline 125 & Dover, DE & 2.74 & 0.00 & 0.53 & 0.07 & 0.26 \\
\hline 126 & LaCrosse, WI & 1.97 & -0.02 & -0.56 & -0.31 & -0.55 \\
\hline 127 & Boise City, ID & 2.02 & -0.02 & -0.69 & -1.45 & -0.50 \\
\hline 128 & Wausau, WI & 1.65 & -0.03 & -1.22 & -0.85 & -1.58 \\
\hline 129 & Greenville, NC & 3.24 & -0.05 & 0.54 & 0.91 & 0.85 \\
\hline 130 & Steubenville-Weirton, WV & 1.42 & -0.09 & & & \\
\hline 131 & Minneapolis-St. Paul, MN & 1.57 & -0.10 & -1.51 & -1.54 & -1.44 \\
\hline 132 & Fayetteville-Springdale, AR & 2.49 & -0.10 & -0.02 & -0.61 & -0.61 \\
\hline 133 & Omaha, NE & 2.36 & -0.10 & -0.65 & -0.93 & -0.86 \\
\hline 134 & Joplin, MO & 1.90 & -0.11 & -0.55 & -0.86 & -0.47 \\
\hline 135 & Sherman-Denison, TX & 3.41 & -0.12 & & & \\
\hline 136 & Waterloo-Cedar Falls, IA & 2.02 & -0.13 & -0.45 & -0.03 & -0.51 \\
\hline 137 & Decatur, IL & 2.23 & -0.14 & -0.22 & 0.10 & -0.56 \\
\hline 138 & Danville, VA & 1.22 & -0.18 & -1.17 & -0.84 & 0.06 \\
\hline 139 & Muncie, IN & 3.25 & -0.18 & -0.12 & 0.23 & 0.55 \\
\hline 140 & Florence, AL & 1.35 & -0.19 & -1.03 & -0.86 & -0.54 \\
\hline 141 & Tyler, TX & 3.72 & -0.20 & 0.08 & 0.25 & 0.02 \\
\hline 142 & New Orleans, LA & 3.63 & -0.20 & -0.49 & -0.21 & 2.00 \\
\hline 143 & Detroit, MI & 1.95 & -0.20 & -1.39 & -1.18 & -0.88 \\
\hline 144 & Mobile, AL & 2.58 & -0.20 & -0.51 & -0.48 & -0.45 \\
\hline 145 & Elkhart-Goshen, IN & 2.83 & -0.20 & -0.46 & -0.56 & 0.02 \\
\hline 146 & Monroe, LA & 2.18 & -0.22 & 0.21 & 0.61 & -0.01 \\
\hline 147 & Texarkana, TX & 1.84 & -0.23 & & & \\
\hline 148 & Jackson, MI & 2.63 & -0.24 & -0.06 & 0.45 & 0.74 \\
\hline 149 & Oklahoma City, OK & 2.38 & -0.24 & 0.41 & 0.23 & \\
\hline 150 & Salem, OR & 3.40 & -0.26 & 0.60 & 0.20 & -0.17 \\
\hline 151 & Shreveport, LA & 2.44 & -0.27 & 0.08 & 0.17 & -0.16 \\
\hline 152 & Erie, PA & 1.96 & -0.27 & -0.86 & -0.44 & -1.06 \\
\hline 153 & Wichita, KS & 2.32 & -0.28 & -0.39 & -0.50 & -0.87 \\
\hline 154 & Philadelphia, PA & 2.18 & -0.28 & -1.06 & -0.96 & -0.97 \\
\hline 155 & Poughkeepsie, NY & 3.65 & -0.29 & & & \\
\hline 156 & Gadsden, AL & 2.12 & -0.30 & -0.60 & -0.20 & -0.96 \\
\hline 157 & Lima, OH & 1.56 & -0.32 & -0.86 & -0.40 & -0.29 \\
\hline 158 & Jackson, TN & 1.74 & -0.33 & -0.46 & -0.31 & -0.62 \\
\hline 159 & Janesville-Beloit, WI & 2.61 & -0.34 & -0.33 & -0.19 & -0.25 \\
\hline 160 & Kankakee, IL & 2.63 & -0.34 & 0.20 & 0.57 & -0.09 \\
\hline 161 & Sheboygan, WI & 2.09 & -0.34 & -1.33 & -0.93 & -0.75 \\
\hline 162 & Lewiston-Auburn, ME & 2.60 & -0.35 & & & \\
\hline 163 & Anniston, AL & 2.65 & -0.36 & 0.16 & 0.36 & 0.24 \\
\hline 164 & Memphis, TN & 2.21 & -0.37 & -0.23 & -0.55 & -0.71 \\
\hline 165 & Cumberland, MD & 0.83 & -0.38 & & & \\
\hline 166 & Rochester, MN & 2.41 & -0.39 & 0.25 & 0.17 & -0.40 \\
\hline 167 & Pittsfield, MA & 2.34 & -0.39 & & & \\
\hline
\end{tabular}




\begin{tabular}{|c|c|c|c|c|c|c|}
\hline \multirow{2}{*}{$\begin{array}{r}\text { Rank } \\
\text { (Gravity Index) }\end{array}$} & \multirow{2}{*}{$\begin{array}{l}\text { Metro Area } \\
\text { Index: } \\
\text { Data: }\end{array}$} & \multirow{2}{*}{$\begin{array}{c}\text { Out Migration } \\
\text { Ann. Rate } \\
\text { IRS }\end{array}$} & \multicolumn{4}{|c|}{ Indices } \\
\hline & & & $\begin{array}{l}\text { Gravity } \\
\text { IRS }\end{array}$ & $\begin{array}{c}\text { Demo. } \\
\text { Census } 2000\end{array}$ & $\begin{array}{l}\text { Demo.+Moved-in } \\
\text { Census } 2000\end{array}$ & $\begin{array}{c}\text { Demo. } \\
\text { ACS }\end{array}$ \\
\hline 168 & Wilmington, NC & 3.08 & -0.39 & 0.63 & 0.47 & 0.21 \\
\hline 169 & Binghamton, NY & 2.26 & -0.41 & 0.47 & 0.89 & -0.78 \\
\hline 170 & Lake Charles, LA & 2.35 & -0.42 & -0.02 & 0.31 & 0.15 \\
\hline 171 & Des Moines, IA & 2.07 & -0.42 & -0.27 & -0.06 & -0.95 \\
\hline 172 & Alexandria, LA & 2.09 & -0.43 & -0.70 & -0.39 & -0.50 \\
\hline 173 & New Haven, CT & 3.91 & -0.43 & -0.19 & -0.10 & 0.20 \\
\hline 174 & Baltimore, MD & 2.79 & -0.45 & -0.61 & -0.68 & -0.68 \\
\hline 175 & Kansas City, MO & 2.11 & -0.45 & -0.84 & -1.28 & -0.85 \\
\hline 176 & Flint, MI & 3.08 & -0.45 & & & \\
\hline 177 & Pueblo, CO & 2.54 & -0.46 & & & \\
\hline 178 & Worcester, MA & 3.70 & -0.46 & -0.25 & 0.08 & -0.22 \\
\hline 179 & South Bend-Mishawaka, IN & 3.14 & -0.49 & 0.18 & 0.32 & 0.18 \\
\hline 180 & Lafayette, LA & 2.50 & -0.49 & -0.30 & 0.15 & -0.13 \\
\hline 181 & Racine, WI & 3.44 & -0.49 & 0.24 & 0.52 & -0.13 \\
\hline 182 & Tulsa, OK & 2.38 & -0.49 & 0.55 & 0.30 & \\
\hline 183 & Hattiesburg, MS & 2.45 & -0.51 & -0.18 & -0.01 & -0.05 \\
\hline 184 & Duluth-Superior, MN & 1.86 & -0.52 & -0.77 & -0.42 & -0.48 \\
\hline 185 & Utica-Rome, NY & 2.32 & -0.52 & -0.05 & 0.58 & -0.70 \\
\hline 186 & Elmira, NY & 1.36 & -0.53 & & & \\
\hline 187 & Lexington-Fayette, KY & 2.26 & -0.53 & 0.33 & 0.42 & -0.16 \\
\hline 188 & Charlotte-Gastonia-Rock Hill, NC & 2.73 & -0.53 & -0.66 & -0.92 & -0.56 \\
\hline 189 & Longview-Marshall, TX & 2.65 & -0.54 & 0.47 & 0.57 & -0.19 \\
\hline 190 & Columbus, $\mathrm{OH}$ & 2.35 & -0.54 & -0.82 & -0.71 & -0.90 \\
\hline 191 & Mansfield, OH & 1.82 & -0.54 & -0.89 & -0.67 & -0.56 \\
\hline 192 & Tuscaloosa, AL & 2.72 & -0.56 & -0.47 & -0.17 & 0.06 \\
\hline 193 & Hartford-Bristol-Middleton-New Britain, CT & 2.95 & -0.57 & -0.92 & -1.00 & -0.96 \\
\hline 194 & Augusta-Aiken, GA & 2.43 & -0.58 & 0.42 & 0.08 & 0.11 \\
\hline 195 & Springfield, IL & 2.26 & -0.59 & & & \\
\hline 196 & Auburn-Opelika, AL & 3.08 & -0.62 & 0.02 & 0.11 & -0.18 \\
\hline 197 & Springfield, MO & 2.05 & -0.62 & -0.36 & -0.55 & -0.41 \\
\hline 198 & Nashville, TN & 2.13 & -0.63 & -0.68 & -0.97 & -0.78 \\
\hline 199 & Columbia, SC & 2.89 & -0.63 & 0.06 & -0.01 & -0.24 \\
\hline 200 & Syracuse, NY & 2.47 & -0.65 & -0.48 & 0.03 & -0.56 \\
\hline 201 & Kokomo, IN & 2.18 & -0.65 & -0.45 & -0.21 & 0.53 \\
\hline 202 & Lansing-E. Lansing, MI & 3.61 & -0.67 & 0.21 & 0.67 & 0.89 \\
\hline 203 & Houma-Thibodoux, LA & 1.62 & -0.68 & -0.97 & -0.45 & -0.75 \\
\hline 204 & Cedar Rapids, IA & 2.36 & -0.68 & -0.18 & 0.06 & -0.57 \\
\hline 205 & Johnstown, PA & 1.61 & -0.70 & -0.97 & -0.34 & -0.54 \\
\hline 206 & Dothan, AL & 1.35 & -0.71 & 0.59 & 0.50 & -0.86 \\
\hline 207 & Terre Haute, IN & 2.02 & -0.73 & -0.59 & -0.30 & -0.36 \\
\hline 208 & Fort Wayne, IN & 2.08 & -0.75 & -0.75 & -0.67 & -0.67 \\
\hline 209 & Macon-Warner Robins, GA & 2.20 & -0.76 & 0.08 & 0.16 & -0.30 \\
\hline 210 & Rochester, NY & 2.00 & -0.77 & -0.75 & -0.37 & -0.76 \\
\hline 211 & Owensboro, KY & 0.96 & -0.77 & & & \\
\hline 212 & St. Louis, MO & 1.58 & -0.78 & -1.14 & -1.10 & -1.22 \\
\hline 213 & Little Rock-North Little Rock, AR & 2.11 & -0.79 & -0.59 & -0.66 & -0.82 \\
\hline 214 & Vineland-Milville-Bridgetown, NJ & 2.81 & -0.80 & 0.47 & 0.70 & 0.08 \\
\hline 215 & Buffalo-Niagara Falls, NY & 1.89 & -0.80 & -0.84 & -0.29 & -0.98 \\
\hline 216 & Decatur, AL & 2.13 & -0.81 & -0.86 & -1.02 & -0.45 \\
\hline 217 & Rockford, IL & 2.48 & -0.82 & -0.40 & -0.43 & -0.16 \\
\hline 218 & Davenport-Rock Island-Moline, IA & 1.81 & -0.83 & -0.93 & -1.07 & -1.48 \\
\hline 219 & St. Joseph, MO & 1.95 & -0.88 & -0.28 & -0.05 & -0.63 \\
\hline 220 & Baton Rouge, LA & 2.23 & -0.89 & -0.69 & -0.43 & -0.66 \\
\hline 221 & Topeka, KS & 2.25 & -0.89 & 0.06 & 0.10 & -0.54 \\
\hline 222 & Williamsport, PA & 1.23 & -0.89 & -1.03 & -0.48 & -1.09 \\
\hline 223 & Milwaukee, WI & 2.15 & -0.90 & -0.92 & -0.73 & -0.94 \\
\hline 224 & Battle Creek, MI & 2.88 & -0.90 & -0.33 & -0.07 & -0.21 \\
\hline 225 & Atlantic City, NJ & 3.45 & -0.93 & 0.06 & -0.20 & 0.13 \\
\hline 226 & Indianapolis, IN & 2.03 & -0.93 & -0.94 & -0.90 & -0.75 \\
\hline 227 & Springfield, $\mathrm{OH}$ & 2.52 & -0.98 & -0.29 & -0.14 & -0.37 \\
\hline 228 & Albany, GA & 1.72 & -1.00 & 0.53 & 0.75 & 0.24 \\
\hline 229 & Beaumont-Port Arthur-Orange, TX & 2.75 & -1.00 & 0.04 & 0.22 & 0.48 \\
\hline 230 & Albany-Schenectady-Troy, NY & 1.69 & -1.01 & -0.91 & -0.48 & -0.99 \\
\hline 231 & Knoxville, TN & 1.94 & -1.01 & -0.84 & -0.85 & -1.07 \\
\hline 232 & Cleveland, $\mathrm{OH}$ & 2.16 & -1.03 & -0.97 & -0.73 & -0.79 \\
\hline 233 & York, PA & 2.74 & -1.04 & -0.58 & -0.39 & -0.54 \\
\hline 234 & Pittsburgh-Beaver Valley, PA & 1.56 & -1.05 & -1.51 & -1.04 & -1.33 \\
\hline 235 & Springfield-Holyoke-Chicopee, MA & 2.59 & -1.09 & -1.20 & -1.10 & -1.02 \\
\hline 236 & Birmingham, AL & 1.98 & -1.14 & -0.82 & -0.59 & -0.47 \\
\hline
\end{tabular}




\begin{tabular}{|c|c|c|c|c|c|c|}
\hline \multirow{2}{*}{$\begin{array}{r}\text { Rank } \\
\text { (Gravity Index) }\end{array}$} & \multirow{2}{*}{$\begin{array}{l}\text { Metro Area } \\
\text { Index: } \\
\text { Data: }\end{array}$} & \multirow{2}{*}{$\begin{array}{c}\text { Out Migration } \\
\text { Ann. Rate } \\
\text { IRS }\end{array}$} & \multicolumn{4}{|c|}{ Indices } \\
\hline & & & $\begin{array}{l}\text { Gravity } \\
\text { IRS }\end{array}$ & $\begin{array}{c}\text { Demo. } \\
\text { Census } 2000 \\
\end{array}$ & $\begin{array}{c}\text { Demo.+Moved-in } \\
\text { Census } 2000\end{array}$ & $\begin{array}{c}\text { Demo. } \\
\text { ACS }\end{array}$ \\
\hline 237 & Providence-Fall River-Pawtucket, RI & 2.42 & -1.17 & -1.46 & -1.33 & -0.61 \\
\hline 238 & Altoona, PA & 1.37 & -1.17 & -1.26 & -0.66 & -0.87 \\
\hline 239 & Toledo, OH & 1.92 & -1.18 & -0.50 & -0.20 & -0.54 \\
\hline 240 & Green Bay, WI & 1.91 & -1.18 & -0.76 & -0.37 & -0.40 \\
\hline 241 & Asheville, NC & 1.91 & -1.19 & -0.53 & -0.63 & -0.11 \\
\hline 242 & Charleston, WV & 1.34 & -1.19 & & & \\
\hline 243 & Wheeling, WV & 1.12 & -1.20 & & & \\
\hline 244 & Lancaster, PA & 2.61 & -1.21 & -0.54 & -0.17 & -0.40 \\
\hline 245 & Akron, OH & 2.36 & -1.22 & -0.69 & -0.34 & -0.59 \\
\hline 246 & Appleton-Oskosh-Neenah, WI & 1.95 & -1.23 & -1.17 & -0.79 & -0.77 \\
\hline 247 & Richmond-Petersburg, VA & 1.98 & -1.23 & 0.74 & 0.74 & 1.58 \\
\hline 248 & Grand Rapids, MI & 1.90 & -1.23 & -1.26 & -0.97 & -0.82 \\
\hline 249 & Jackson, MS & 1.55 & -1.29 & -0.95 & -0.68 & -0.41 \\
\hline 250 & Burlington, NC & 2.10 & -1.29 & -0.82 & -0.82 & -0.72 \\
\hline 251 & Reading, PA & 2.82 & -1.29 & -0.61 & -0.18 & -0.28 \\
\hline 252 & Fort Smith, AR & 1.36 & -1.30 & -0.77 & -1.15 & -0.23 \\
\hline 253 & Cincinnati, OH & 1.72 & -1.31 & -0.86 & -0.76 & -0.64 \\
\hline 254 & Saginaw-Bay City-Midland, MI & 1.76 & -1.33 & -0.87 & -0.41 & -0.79 \\
\hline 255 & Peoria, IL & 1.75 & -1.42 & -0.84 & -0.55 & -0.58 \\
\hline 256 & Parkersburg-Marietta, WV & 0.75 & -1.44 & & & \\
\hline 257 & Chattanooga, TN & 1.55 & -1.44 & -2.74 & -3.19 & -2.02 \\
\hline 258 & Youngstown-Warren, OH & 1.78 & -1.48 & -0.98 & -0.73 & -0.60 \\
\hline 259 & Louisville, KY & 1.30 & -1.50 & -1.14 & -1.11 & -1.38 \\
\hline 260 & Evansville, IN & 1.02 & -1.52 & -1.25 & -1.19 & -0.97 \\
\hline 261 & Harrisburg-Lebanon-Carlisle, PA & 2.33 & -1.54 & -0.26 & 0.16 & -0.40 \\
\hline 262 & Rocky Mount, NC & 1.98 & -1.58 & & & \\
\hline 263 & Greenville-Spartanburg-Anderson, SC & 1.66 & -1.63 & -1.19 & -1.29 & -0.81 \\
\hline 264 & Florence, SC & 1.75 & -1.70 & & & \\
\hline 265 & Allentown-Bethlehem-Easton, PA & 2.42 & -1.78 & -0.62 & -0.40 & -0.40 \\
\hline 266 & Scranton-Wilkes-Barre, PA & 1.40 & -1.81 & -1.63 & -1.20 & -1.35 \\
\hline 267 & Hagerstown, MD & 1.86 & -1.86 & -0.50 & -0.62 & -0.14 \\
\hline 268 & Huntington-Ashland, WV & 1.05 & -1.94 & & & \\
\hline 269 & Hickory-Morgantown, NC & 1.10 & -1.97 & -1.46 & -1.29 & -0.85 \\
\hline 270 & Lynchburg, VA & 1.53 & -2.01 & -0.73 & -0.55 & -0.29 \\
\hline 271 & Roanoke, VA & 1.50 & -2.02 & & & \\
\hline 272 & Johnson City-Kingsport-Bristol, TN & 0.70 & -2.44 & -1.46 & -1.65 & -0.96 \\
\hline
\end{tabular}

